\title{
Protein arginine methylation: an emerging regulator of the cell cycle
}

\author{
Anita E. Raposo and Sabine C. Piller
}

\begin{abstract}
Protein arginine methylation is a common post-translational modification where a methyl group is added onto arginine residues of a protein to alter detection by its binding partners or regulate its activity. It is known to be involved in many biological processes, such as regulation of signal transduction, transcription, facilitation of protein-protein interactions, RNA splicing and transport. The enzymes responsible for arginine methylation, protein arginine methyltransferases (PRMTs), have been shown to methylate or associate with important regulatory proteins of the cell cycle and DNA damage repair pathways, such as cyclin D1, p53, p21 and the retinoblastoma protein. Overexpression of PRMTs resulting in aberrant methylation patterns in cancers often correlates with poor recovery prognosis. This indicates that protein arginine methylation is also an important regulator of the cell cycle, and consequently a target for cancer regulation. The effect of protein arginine methylation on the cell cycle and how this emerging key player of cell cycle regulation may be used in therapeutic strategies for cancer are the focus of this review.
\end{abstract}

Keywords: Protein arginine methylation, Cell cycle regulation, p53, Cancer, DNA repair

\section{Background}

The cell cycle allows cells to divide and is characterised by the replication of DNA and the subsequent division of duplicated chromosomes into two daughter cells [1]. Regulatory proteins including the tumor suppressor protein $\mathrm{p} 53$ and the retinoblastoma protein $(\mathrm{pRb})$ monitor the cell cycle and initiate pathways in response to DNA damage [2]. Cancer is considered to be a disease of the cell cycle [3] and as such these cell cycle regulatory proteins are often found to be deregulated in cancer. Protein arginine methylation is a post-translational modification often upregulated in cancer and other diseases [4], contributing to the deregulation of the cell cycle.

This review will discuss the current understanding of the role protein arginine methylation plays in cell cycle regulation and the implications for potential cancer treatment.
*Correspondence: s.piller@westernsydney.edu.au

School of Science and Health, Western Sydney University, Penrith, NSW 2751, Australia

\section{Cell division}

The controlled regulation of cell division is essential in growth, repair and re-generation of healthy tissues and occurs via the cell cycle. The cell cycle is divided into non-overlapping stages or phases which are referred to as gap $1\left(G_{1}\right)$, synthesis $(S)$, gap $2\left(G_{2}\right)$ and mitosis $(M)$ phase [5] (Fig. 1). In the $G_{1}$ phase, the cell is preparing for DNA replication which then occurs in the $S$ phase, while cells in the $G_{2}$ phase are preparing for the $M$ phase, where cell division takes place [5]. M phase can be further divided into prophase, metaphase, anaphase, telophase and cytokinesis [6]. For a visual review of mitotic regulation see [7]. Cells that are not actively dividing are said to be in $G_{0}$, a resting or quiescent phase. Once cells have committed to DNA replication they cannot return to $G_{0}[1]$. In order to guarantee successful cell division without errors, the cell cycle is stringently regulated. Deregulation of the cell cycle, resulting in uncontrolled cell proliferation is one of the hallmarks of cancer [8].

\section{Cell cycle regulation}

Regulation of the cell cycle is mainly achieved by a family of serine/threonine kinases called cyclin-dependent kinases (CDKs). However, full CDK activation only 


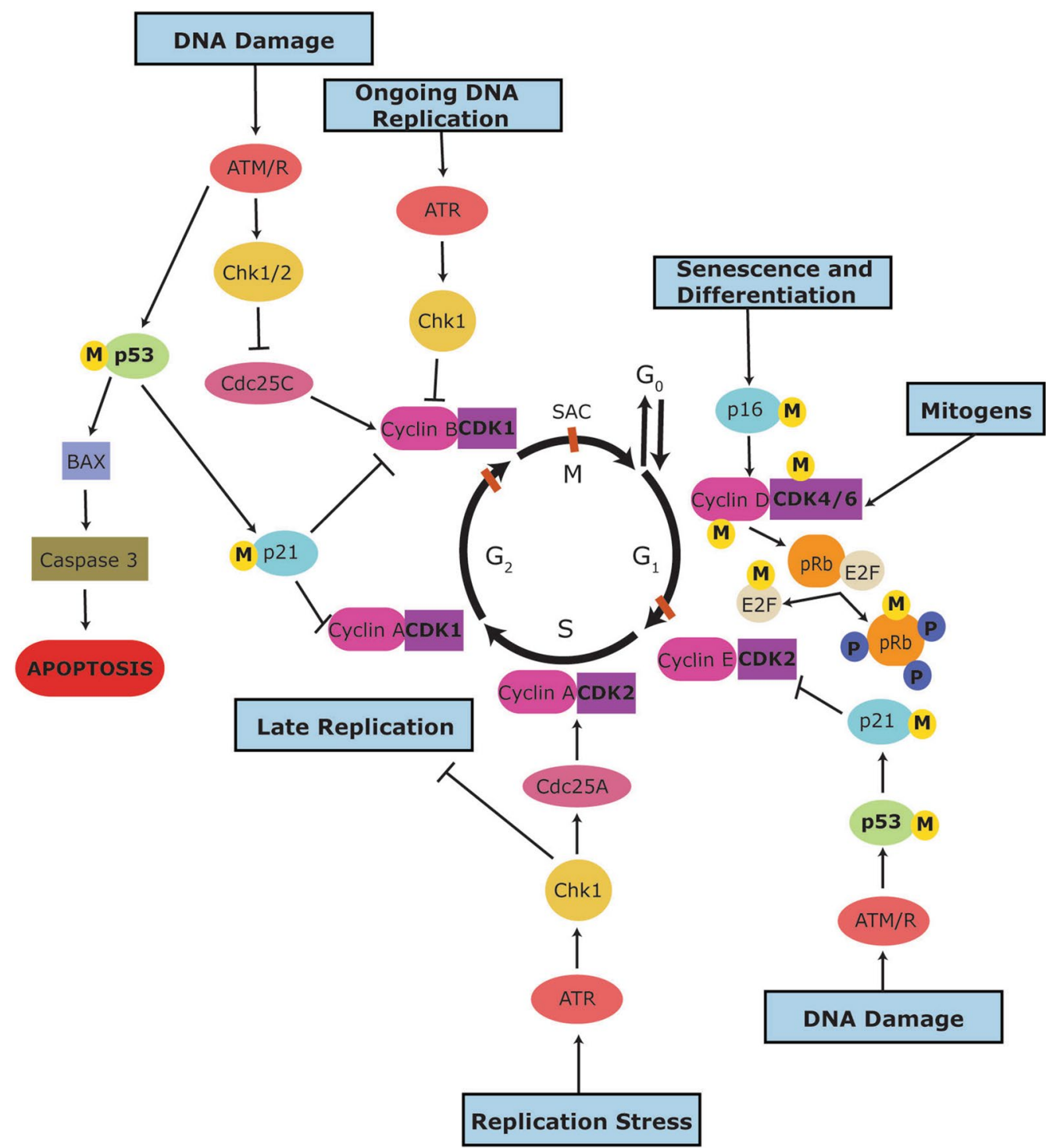

Fig. 1 Overview of the regulation of the cell cycle. The cell cycle is depicted as a circle where each black arrow represents one phase of the cell cycle. Cells enter the cell cycle into the G1 phase, which is followed by the S phase, G2 phase and then mitosis (M). The cell cycle is regulated by CDKs (purple), their regulatory subunit cyclins (pink), CDK inhibitors such as p21 (light blue), and other regulatory kinases, such as the checkpoint kinases 1 and 2 (Chk1 and Chk2; yellow). The orange lines at the end of G1, G2 and during mitosis indicate cell cycle checkpoints where the cell is monitored for defects during replication and can respond by the p53 (green) pathway or the ATM/R (red) pathway, among others. Yellow circles with " $\mathrm{M}$ " indicate proteins known to be methylated on arginine residues and the dark blue circles with " $\mathrm{P}$ " indicate phosphorylation of pRB

occurs upon the association of a CDK and a cyclin subunit [9]. CDKs allow cell cycle phase transitions to occur [10]. Nine CDKs have been identified with five of them found to be active as complexes with various cyclin subunits during the cell cycle $[11,12]$. CDK levels remain constant throughout the cell cycle, while the levels of cyclin proteins rise and fall during the cell cycle to activate CDKs when they are required [13]. Cyclin D1 is overexpressed in $50 \%$ of breast cancers [14], and at lower frequencies in many other cancers including prostate cancer [15]; while Cyclin E has been reported to be deregulated in malignant tumors of the lung, breast, gastrointestinal tract and in ovarian cancer [16].

Although CDK levels remain constant throughout the cell cycle, their activity is regulated by phosphorylation on specific residues to induce conformational changes and enhance cyclin binding. For example, full activation of CDK2 requires phosphorylation on threonine 160 by 
the CDK7-cyclin $\mathrm{H}$ complex also called the CDK activating kinase (CAK) [17]. Inhibitory kinases, such as Wee1 and Myt1 can function as inactivators of CDK1 by phosphorylating it. Dephosphorylation is then required for CDK1 reactivation [18]. Cyclin dependent kinase inhibitors (CDKIs) regulate CDK activity by binding to CDKs or the CDK-cyclin complex [1]. There are two families of CDKIs which have been discovered so far: Inhibitors of CDK4 (INK4) proteins and CDK interacting proteins/ kinase inhibitory proteins (CIP/KIP) [1] (Fig. 1). The INK4 inhibitors (p15 $5^{\text {INK4b }}, \mathrm{p} 16^{\text {INK4a }}, \mathrm{p} 18^{\text {INK4c }}, \mathrm{p} 19^{\text {INK4d }}$ ) specifically inactivate the cyclin D-dependent CDKs, i.e. CDK4 and CDK6, by competitively binding these CDKs and preventing them from forming a complex with cyclin $\mathrm{D}$ [19]. The CIP/KIP inhibitors (p21 ${ }^{\mathrm{CIP} 1}, \mathrm{p} 27^{\mathrm{KIP} 1}, \mathrm{p} 57^{\mathrm{KIP} 2}$ ) bind to and inactivate multiple G1 CDK-cyclin complexes [20]. p21 also binds to the proliferating cell nuclear antigen (PCNA), inhibiting DNA replication [21]. CDKIs are themselves regulated by internal and external signals. For example, the p 21 gene promoter encodes a p53 binding site allowing p53 to transcriptionally activate the p 21 gene [22]. The expression of p15 and activation of p27 both increase in response to transforming growth factor $\beta$ [20]. CDK inhibitors, such as p15 and p18, are frequently deregulated in cancer [3], allowing uncontrolled progression into $S$ phase [23].

The Phosphatidylinositol 3-kinase (PI3K) pathway regulates cellular processes through its association with the protein kinase $A K T$ and is involved in the $G_{1} / S$ phase transition of the cell cycle [24]. AKT prevents cyclin D1 degradation by directly phosphorylating glycogen synthase kinase $3 \beta$ (GSK3 $\beta$ ), blocking its kinase activity and allowing cyclin D1 to accumulate [25]. (PI3K)/AKT signaling is frequently deregulated in human cancers, including ovarian, breast, lung, thyroid and melanomas [26]. The tumor suppressor Phosphatase and tensin homolog (PTEN) gene is a negative regulator of the PI3K/AKT signaling pathway [27] and is one of the most mutated or deleted genes across different cancer types [28], leading to deregulation of the PI3K/AKT pathway.

\section{Cell cycle checkpoints}

In addition to the cell cycle regulation by CDKs and CDKIs, there are several checkpoints, such as the DNA repair checkpoints that regulate $G_{1} / S$ and $G_{2} / M$ phase transitions (see Fig. 1), where cell size, extracellular growth signals [3], and progression through the cell cycle are monitored to prevent defects or to repair any DNA damage which may have occurred during DNA synthesis [29]. It is these DNA defects, which if left unrepaired, are passed onto daughter cells during cell division and contribute to the deregulation of the cell cycle and may lead to the unrestrained cell proliferation characteristics of cancer [1].

DNA damage checkpoints occur before cells enter $\mathrm{S}$ phase $\left(G_{1}-S\right.$ checkpoint $)$ where cell cycle arrest induced by DNA damage is p53 dependent; or after DNA replication, with or without the tumour suppressor protein, p53 ( $\mathrm{G}_{2}-\mathrm{M}$ checkpoint) [30]. The checkpoint kinase proteins, Chk1 and Chk2, phosphorylate the cell division cycle phosphatases, Cdc25, to regulate the phosphorylation of CDK1 and CDK2, and therefore regulate $G_{1}$ into $S$ phase and $S$ phase into $G_{2} / M$ transitions, respectively. DNA damage repair is also monitored during $\mathrm{S}$ phase to block replication, if damaged DNA has escaped the $G_{1} / S$ phase checkpoint without undergoing repair [31].

The spindle assembly checkpoint (SAC) detects the improper alignment of chromosomes on the mitotic spindle and can stop the cell cycle in metaphase, if required, to prevent the formation of cells with the incorrect number of chromosomes [32]. This checkpoint is controlled by the mitotic-arrest deficient (mad) and the budding uninhibited by benzimidazole (bub1) families of genes [33, 34]. The mitotic checkpoint complex (MCC) consists of MAD2, BUBR1 and BUB3 proteins and negatively regulates the activity of cell division cycle protein 20 (CDC20) [35-38]. CDC20 binds to the ubiquitin ligase anaphase-promoting complex/cyclosome (APC/C) [38], preventing the APC/C from exerting its ubiquitinylation activity on securin and cyclin B [39]. Securin is an inhibitor of the protease separase which is required to cleave the cohesion complex which holds sister chromatids together [40], while cyclin B is required to activate CDK1 to promote exit of the cells from mitosis [41]. Thus, inhibition of the APC/C by the MCC prevents cells from entering anaphase. Other important SAC proteins include MAD1, BUB1, MAPK and Aurora $B$, which promote recruitment of the SAC proteins to the kinetochores [42]. Aurora B is also involved in correcting aberrant merotelic attachment of kinetochores to microtubules from opposite poles to prevent the division of cells with the improper number of chromosomes [43]. Ubiquitin-associated protein 2-like (UBAP2L) is also necessary for proper kinetochore/microtubule attachment and depletion of UBAP2L activates SAC signalling, delaying progression into anaphase [44]. For a comprehensive review on the SAC see [45].

\section{DNA damage repair}

DNA damage can be induced via a variety of triggers (including UV radiation, chemicals, and stress) and if left unrepaired can lead to cancer. Therefore, cells respond to unrepairable DNA damage by stopping cell cycle progression or by initiating programmed cell death via several pathways. 
Depending on the type of DNA damage, five major pathways of DNA repair are utilised by cells including: direct repair, base excision repair, nucleotide excision repair, mismatch and recombinational repair, and double strand break repair [46]. These repair pathways will be briefly explained here but the reader is referred to other reviews [47-51] for a more comprehensive coverage.

In mammalian cells, alkylation damage is repaired by direct repair alkyltransferases. $\mathrm{O}^{6}$-methylguanine-DNA methyltransferase is the main enzyme facilitating direct repair by transferring a methyl group from the DNA backbone into the active site of the enzyme [52].

Three excision repair mechanisms remove specific types of damage: Firstly, base excision repair (BER) specifically recognizes base damage. It most commonly deals with base damage that occurs during normal aerobic metabolism via reactive oxygen species (most common base damage: dihydro-8-oxoguanine). BER requires removal of the damaged DNA base by a specific DNA glycosylase to initiate the process [51]. Short nucleotide gaps are then re-synthesized via APE1, DNA polymerase $\beta$ [53] and the Ligase 3/XRCC1 complex; while longer breaks of 2-10 nucleotides are repaired by the RFC/ PCNA-DNA polymerase $\delta / \varepsilon$ complex [54]. Secondly, nucleotide excision repair is the major pathway for the removal of bulky DNA lesions formed by exposure to environmental sources, ultraviolet radiation or chemicals [55]. In humans, the process of nucleotide excision repair involves damage recognition, incision around the lesion to release a 24-32 nucleotide oligomer and repair of the resulting gap by DNA polymerase $\delta / \varepsilon$ and ligation. For a review on nucleotide excision repair see [56]. In humans, nucleotide excision repair requires more than 30 proteins to successfully execute the repair [55]. Repair proteins including XPA, RPA, XPC, TFIIH, XPG and XPF-ERCC1 perform these functions [57-59]. Thirdly, mismatch repair functions to repair errors such as mismatches, insertions or deletions that can occur during replication [50].

Double strand breaks (DSBs) are the most lethal type of damage to the cell. DSB damage occurs when cells are exposed to ionizing radiation and during normal cellular recombination and immunoglobulin class-switching processes [60]. DSBs can be repaired via homologous recombination or non-homologous end-joining (NHEJ) [61]. Homologous recombination occurs at a homologous stretch of DNA on a sister chromatid serving as a template to guide repair of the broken strand, while NHEJ requires enzymes to capture the ends of the broken DNA, bringing them together in a DNA-protein complex, then the DNA break is repaired via ligation [62]. Both require the proteins NBS1 [63], MRE11 [64], and Rad50 [65]. Homologous recombination also requires the heterodimer MUS81-MMS4 [46], BRCA1 and BRCA2 [66], while NHEJ requires DNA-PKCs and the heterodimer Ligase 4-XRCC4 [67].

DNA strand crosslinks can be induced by many chemotherapeutic drugs and can stall DNA replication, leading to cell death [68]. Depending on the type of cross-link, they are processed either by nucleotide excision repair (intra-strand cross-link) or converted into a double-stranded DNA break and processed by homologous recombination (inter-strand crosslink) [69]. Hence, the same repair proteins are utilised, such as XPF-ERCC1 to degrade one of the cross-linked strands [70]; or the recombination proteins $\operatorname{Rad} 51$ and Rad52 to promote homologous DNA pairing and strand exchange [65].

DNA damage repair can also be initiated by tumor suppressor proteins which can induce cell cycle arrest to either initiate repair or mark the cell for apoptosis. Two such proteins that regulate the major pathways of apoptosis and cellular progression are $\mathrm{p} 53$ and $\mathrm{pRb}$ [10]. Between them, these two proteins can initiate differentiation, DNA repair, cell cycle arrest or progression and induction/inhibition of apoptosis. The $\mathrm{p} 53$ and pRb pathways are summarised in the following sections.

\section{p53}

p53 is normally expressed at low levels but rises within cells in response to various stimuli, such as DNA damage, hypoxia and oncogene activation, to activate various pathways that initiate differentiation, DNA repair, cell cycle arrest, inhibition of angiogenesis and apoptosis [71]. There are three main responses that p53 can initiate: (1) facilitation of cell cycle arrest by inducing the expression of p21, 14-3-3 proteins, Cdc25C and GADD45 [72]; (2) stimulation of DNA repair by inducing the expression of p21, GADD45 and p48 [10]; and (3) induction of apoptosis by upregulating the transcription of BAX and other apoptotic proteins [73]. Low levels of stress or DNA damage induce p53-mediated cell cycle arrest, while high levels of stress activate p53-mediated apoptotic pathways [74]. Further, different protein kinases such as ataxiatelangiectasia mutated (ATM) and ataxia-telangiectasia and Rad3 related (ATR) phosphorylate p53 in response to DNA damage, leading to $\mathrm{p} 21$ arresting the cell cycle at the $\mathrm{G}_{1}-\mathrm{S}$ checkpoint $[47,75]$ (see Fig. 1). Inactivation of the p53 gene results in the dysfunction of proteins that would normally inhibit cell cycle proliferation [1]. The inactivation of the p53 gene through mutations is the most commonly occurring loss of a pro-apoptotic regulator and is seen in more than $50 \%$ of cancers [76].

\section{Retinoblastoma protein}

$\mathrm{pRb}$ interacts with proteins involved in transcriptional control such as the E2F proteins that are regulators of 
gene expression and genes involved in DNA replication, DNA repair and $G_{2} / M$ progression [77] (Fig. 1). pRb regulates cell cycle arrest by binding to E2F. E2F and its heterodimer, the transcription factor DP, are mediators of the $\mathrm{p} 16 / \mathrm{pRb}$ pathway of $\mathrm{G}_{1}$ cell cycle arrest [78]. However, only unphosphorylated forms of $\mathrm{pRb}$ can interact with E2F proteins [79] (Fig. 1). Thus, phosphorylation of $\mathrm{pRb}$ carried out by the CDK4-cyclin D1 complex regulates $\mathrm{pRb}$ function [80]. $\mathrm{pRb}$ is found to be unphosphorylated during $G_{0}$ and $G_{1}$ phase, and phosphorylated during the remainder of the cell cycle [81].

Phosphorylation clearly plays a pivotal role in cell cycle regulation. Protein methylation is a post-translational modification that may be just as important in cell cycle regulation as phosphorylation.

\section{Protein arginine methylation}

During protein methylation, a methyl group is added to a specific protein residue to alter detection by its binding partners or to regulate its activity [82]. This can occur on lysine $(\mathrm{K})$, histidine $(\mathrm{H})$ or arginine $(\mathrm{R})$ residues of both histones and non-histone proteins [83]. Protein arginine methyltransferases were discovered almost 50 years ago and while histone and non-histone protein lysine methylation have been extensively studied over the past 60 years, protein arginine methylation has only gained more attention in the past 20-25 years [84].

Protein arginine methylation has many documented regulatory roles including in signal transduction [85], transcription [86, 87], protein-protein interactions such as facilitating the interactions of Tudor domains with glycine arginine rich (GAR) and proline glycine methionine (PGM) motifs in proteins [88], RNA transport [89], and RNA splicing [90, 91]. For a recent review that covers arginine methylation in different organ systems, see [92].

\section{Protein arginine methyltransferases}

In 1968, Paik and Kim attempted to purify the enzyme responsible for the methylation of histone lysine residues [93]. The enzyme they discovered, protein methylase I, was not a lysine methyltransferase but actually a protein arginine methyltransferase or PRMT [93], now known as PRMT1. There are currently eleven PRMTs which are divided into four enzyme types [94]. For a review see $[82,95,96]$. Types I to III exist in mammalian cells and all catalyse the addition of a single methyl group onto a terminal nitrogen atom of arginine residues forming $\omega-N^{G}$-monomethyl arginine (MMA). Type I enzymes are the most common [4] and catalyse the addition of another methyl group onto the same terminal nitrogen atom, forming $\omega-N^{\mathrm{G}}, N^{\mathrm{G}}$-dimethylarginine or asymmetric dimethylarginine (ADMA) [97]. Type II enzymes catalyse the addition of another methyl group onto the other terminal nitrogen atom, producing $\omega-N^{G}$, $N^{\mathrm{G}}$-dimethylarginine or symmetric dimethylarginine (SDMA) [98]. Type III enzymes only catalyse the formation of MMA [99]. While Type IV enzymes also catalyse the formation of MMA, the methyl group is added to the internal $(\sigma)$ guanidino nitrogen atom and this has so far only been described in yeast [100]. The structures of the three methylarginine types present in mammals (MMA, ADMA, and SDMA) are shown in Fig. 2.

\section{Regulation of the cell cycle by arginine methylation}

The interaction of many key regulatory proteins of the cell cycle with several PRMTs has been characterised and/or methylated residues have been identified (for summary see Table 1). It should be noted that these findings, while representative of the cell type and/or tissue types examined, may not be representative of all tissues especially as cancer is notorious for differing mutations between patients. While there had been earlier indications that arginine methylation may be involved in cell proliferation, a study by Kim et al. [101] was one of the first to describe the involvement of protein arginine methylation in the different phases of the cell cycle in HeLa cells.

\section{PRMT1}

As the most abundant PRMT [102], the majority of PRMT1 activity can be described as anti-proliferative and/or tumor-suppressor-inducing. Recent work has revealed that PRMT1 binds to the tumor suppressor, BGT2, to play a role in pre-B cell differentiation [103]. The BGT2-PRMT1 complex destabilizes the binding of CDK4 to cyclin D3 through the methylation of CDK4 at arginines 55, 73, 82 and 163, halting cell cycle progression and leading to pre-B cell differentiation [103]. E2F1 is competitively methylated by PRMT1 and PRMT5 [104]. Methylation by PRMT1 stabilizes E2F1 during DNA damage [105] and assists in E2F1-dependent apoptosis [104], while methylation by PRMT5 promotes cellular proliferation [104, 106]. Interestingly, recent publications have brought to light the interplay between arginine methylation and serine phosphorylation, adding an extra layer of complexity to the regulation of the cell cycle. For example, methylation of p16 at arginine 138 by PRMT1 increases as phosphorylation of p16 at serine 140 decreases, and vice versa in $293 \mathrm{~T}$ cells [107]. These modifications work antagonistically to regulate the interaction of p16 with CDK4 [107], thus regulating cell proliferation and apoptosis.

\section{PRMT2}

It is unclear at this stage whether PRMT2 has pro-proliferative or anti-proliferative functions in cancer. Arginine 


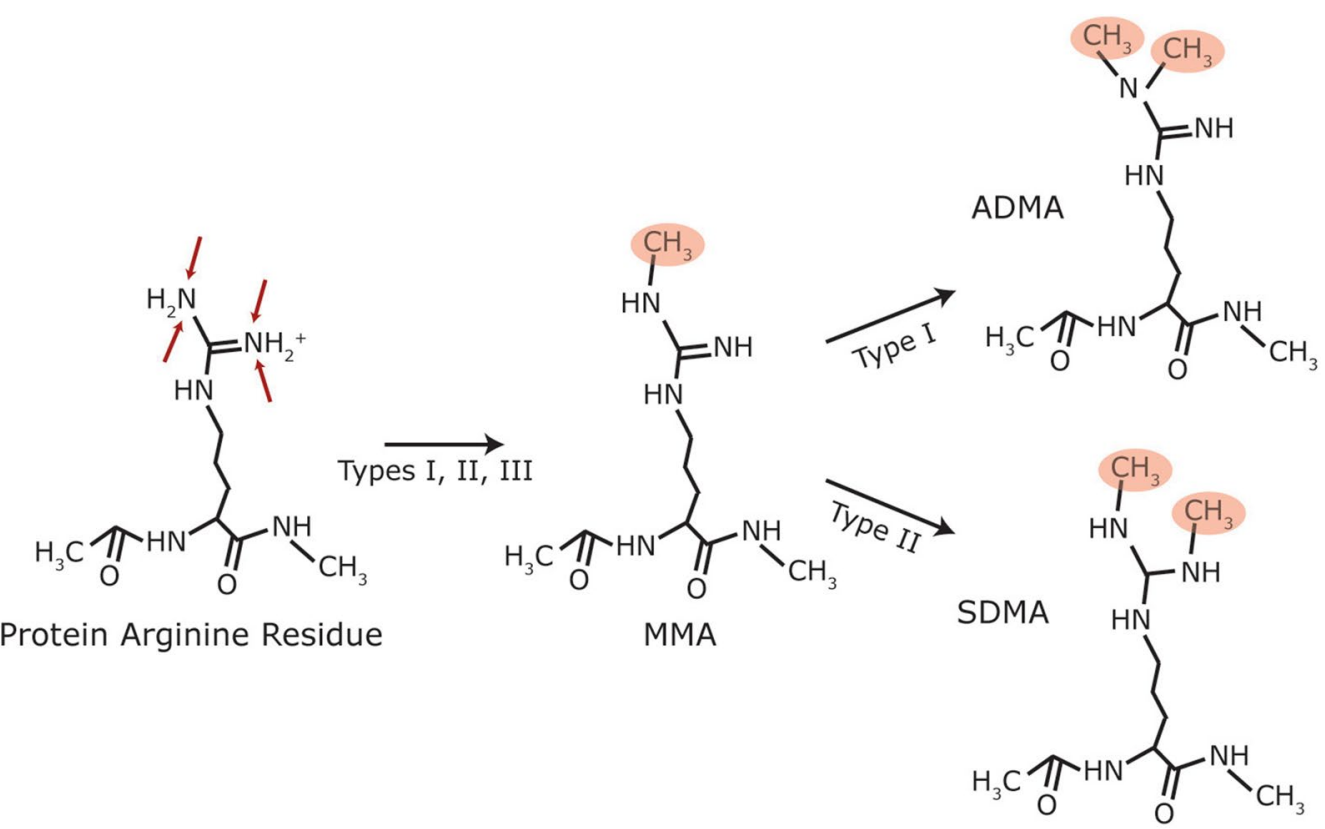

Fig. 2 Types of mammalian protein arginine methylation. Arginine residues in proteins can be monomethylated by type I, II and III PRMTs to form MMA, while type I and II PRMTs further methylate to produce ADMA and SDMA residues, respectively. Red arrows indicate known methylation locations in mammalian cells; red circles indicate methyl groups

Table 1 Key cell cycle regulators known to be substrates and interacting partners of PRMTs

\begin{tabular}{|c|c|c|c|c|}
\hline Protein & $\begin{array}{l}\text { Interacting } \\
\text { PRMT }\end{array}$ & $\begin{array}{l}\text { Known methylated } \\
\text { residues }\end{array}$ & Result of methylation or PRMT interaction & Refs. \\
\hline BGT2 & PRMT1 & - & BGT2 regulates $P R M T 1$ activity in pre-B cells & [103] \\
\hline \multirow[t]{2}{*}{ CDK4 } & PRMT1 & R55, R73, R82, R163 & Destabilization of CDK4-cyclin D3 complex leading to pre-B cell differentiation & [103] \\
\hline & PRMT5 & - & Interaction of CDK4 and PRMT5 regulates pRb/E2F-mediated transcription & [119] \\
\hline \multirow[t]{2}{*}{ Cyclin D1 } & PRMT2 & - & Knockdown of PRMT2 correlates with increased cyclin D1 & [111] \\
\hline & PRMT5 & - & Increased nuclear PRMT5 correlates with increased cyclin D1 protein levels & {$[121]$} \\
\hline \multirow[t]{3}{*}{ E2F1 } & PRMT1 & R109 & Assists E2F1-dependent apoptosis during DNA damage & {$[104,105]$} \\
\hline & PRMT4 & - & Regulates E2F expression & [113] \\
\hline & PRMT5 & $\mathrm{R} 111, \mathrm{R} 113$ & Promotes cell proliferation & {$[104,106]$} \\
\hline Fanca & PRMT5 & - & Regulation of PRMT5-mediated methylation of p53 & [131] \\
\hline \multirow[t]{3}{*}{ p16 } & PRMT1 & R138 & Regulates p16 and CDK4 interaction to regulate cell proliferation & [107] \\
\hline & PRMT5 & - & $\begin{array}{l}\text { Increased nuclear PRMT5 negatively correlates with p16 protein expression and } \\
\text { is associated with poor survival }\end{array}$ & [121] \\
\hline & PRMT6 & $R 22, R 131, R 138$ & Methylation of $\mathrm{p} 16$ reduces binding of p16 with CDK4 & [136] \\
\hline \multirow[t]{3}{*}{ p21 } & PRMT2 & - & Knockdown of PRMT2 correlates with increased p21 expression & [110] \\
\hline & PRMT6 & - & Inhibition allowing cell cycle progression & [132] \\
\hline & & R156 & Increased cytoplasmic localisation of p21, resulting in resistance to doxorubicin & [135] \\
\hline p27 & PRMT6 & - & Inhibition allowing cell cycle progression & [132] \\
\hline \multirow[t]{2}{*}{ p53 } & PRMT5 & R333, R335, R337 & $\begin{array}{l}\text { Affects promoter specificity of p53 and enhances p53-dependent cell cycle } \\
\text { arrest }\end{array}$ & [127] \\
\hline & Unknown & R213 & Mediates p21 activation for cell cycle progression & [129] \\
\hline \multirow[t]{2}{*}{$\mathrm{pRb}$} & PRMT2 & - & $\begin{array}{l}\text { Repression of E2F transcriptional activity and cell cycle progression by binding } \\
\text { to } \mathrm{pRb}\end{array}$ & [108] \\
\hline & PRMT4 & R775, R787, R798 & Decreases binding of pRb to E2F-1 leading to increased cell proliferation & [109] \\
\hline
\end{tabular}


methylation of $\mathrm{pRb}$ by PRMT2 contributes to E2F1 transcriptional regulation for progression into $S$ phase [108] by impairing pRb/E2F1 binding [109]. Recently, PRMT2 levels were found to be decreased in breast cancer cells, while knockdown of PRMT2 correlated with increased expression of both p21 [110] and cyclin D1 [111] indicating a regulatory role for PRMT2 in cell cycle progression. Further studies are needed to clarify the exact functions of PRMT2 in cell cycle progression.

\section{PRMT4}

PRMT4 appears to have pro-proliferative functions and may have a pro-oncogenic role in some cancers. Expression of Cyclin E1 rises sharply leading into $\mathrm{S}$ phase to allow transition into the $S$ phase [6], and levels of cyclin E1 are frequently deregulated in breast cancer [16]. PRMT4 is a positive regulator of the Cyclin E1 gene, by acting as a transcriptional co-activator of ACTR coinciding with histone methylation of the CCNE1 promoter region [112]. PRMT4 is essential for estrogen induced cell cycle proliferation in breast cancer by the positive regulation of E2F1 RNA and protein expression [113]. In addition, increased expression of PRMT4 may contribute to the development of prostate cancer, as it correlates with the androgen independence required for the progression of aggressive tumours [114]. Interestingly, a decrease in PRMT4-mediated methylation of $\mathrm{pRb}$ led to a decrease in its phosphorylation, suggesting arginine methylation can increase $\mathrm{pRb}$-mediated cell proliferation [109].

\section{PRMT5}

The most studied type II PRMT, PRMT5, has pro-proliferative and pro-oncogenic roles, as described below, even though it appears to have the opposite effect in Fanconi anemia patients. This highlights that the effect of specific PRMTs and their inhibition may not be the same in all types of cancers and may differ in individual patients.

PRMT5 is essential for cell proliferation [115] and correlates with increased protein expression of the $G_{1}$ phase regulators CDK4 and CDK6 [116]. Deficiency of PRMT5 triggers cell-cycle arrest in the $G_{1}$ phase [117]. Overexpression of PRMT5 correlates with increased cell proliferation and knockdown of PRMT5 results in cell cycle arrest leading to apoptosis [118]. CDK4 interacts with PRMT5 in HepG2 cells which regulates phosphorylation of $\mathrm{pRb}$, thus regulating $\mathrm{pRb} / \mathrm{E} 2 \mathrm{~F}$-mediated transcription [119]. Disruption of the PRMT5/CDK4 interaction revealed PRMT5 knockdown HepG2 cells to be more sensitive to the CDK4 inhibitor fascaplysin, marking the combination of PRMT5 and CDK4 inhibition as a potential cancer therapy [119]. PRMT5 deficiency also led to apoptosis in differentiated glioblastoma cells however, in glioblastoma neurospheres it led to $G_{1}$ cell cycle arrest through increased protein expression of $\mathrm{p} 27$ and a decrease in phosphorylation of pRb [120]. PRMT5 expression correlated with cyclin D1 protein levels, while also inversely correlating with p16 levels [121]. Nuclear PRMT5/p16-negative tumors were associated with poor prognosis in oropharyngeal squamous cell carcinoma when compared to nuclear PRMT5-negative/p16- positive tumors [121]. PRMT5 is found to be overexpressed in many cancer types, including glioblastoma [118, 122], lung [123], mantle cell lymphoma [124], ovarian [125] and prostate cancer [126]. In all these studies, knockdown of PRMT5 slowed or inhibited cell proliferation, indicating the enzyme may be affecting key regulators of cell proliferation.

p53-dependent cell cycle arrest is enhanced by methylation of p53 by PRMT5 [127], while reduced expression of p53 during the DNA damage response is triggered by PRMT5-deficiency [117]. While the methylation of p53 at arginine 213 may be controversial [128], mutation of this residue resulted in a decrease of p21 RNA and protein expression directly affecting the $S$ phase of the cell cycle [129]. This indicates that $\mathrm{p} 21$ activation by $\mathrm{p} 53$ may be mediated by arginine methylation of R213 [129].

Fanconi anemia is a genetic disorder characterized by a high risk of developing cancer, among other clinical characteristics, due to a cellular hypersensitivity to DNA cross-linking agents and faulty DNA damage repair pathways [130]. Fanconi anemia proteins, FANCA-C, E-G, $\mathrm{L}$ and $\mathrm{M}$, form a "core complex" which activates DNA repair pathways. In $\mathrm{FanCa}^{-/-}$and $\mathrm{Fancc}^{-1-}$ mice, arginine methylation of $\mathrm{p} 53$ by PRMT5 was decreased in response to oncogenic stress [131]. Interestingly, forced expression of PRMT5 led to the delayed onset of leukemia in irradiated mice [131], indicating that PRMT5 may play a tumor suppressor role in Fanconi anemia patients.

\section{PRMT6}

PRMT6 may have pro-proliferative and pro-oncogenic functions in both colon and lung cancers. PRMT6 inhibits p21 along with p27, allowing cell cycle progression through the cyclin dependent kinases 1 and 2 (CDK1/2) [132-134]. Methylation at arginine 156 of the p21 protein by PRMT6 increased the cytoplasmic localisation of p21 and resulted in HCT116 colon cancer cells becoming more resistant to the chemotherapy drug, doxorubicin [135]. Methylation of p16 at arginine 138 by PRMT6 caused reduced binding of p16 to CDK4, leading to increased cellular proliferation in A549 cells [136]. Further studies are required to determine the function of PRMT6 in other types of cancers. 


\section{Regulation of the DNA damage repair by arginine methylation}

Proteins involved in the DNA damage repair pathways are regulated by protein arginine methylation (see Table 2). Arginine methylation of Heterogeneous Nuclear Ribonucleoprotein U-Like 1 (hnRNPUL1) by PRMT1 regulates the interaction of hnRNPUL1 with Nijmegen Breakage Syndrome 1 (NBS1) [137], a component of the double strand DNA break repair complex with MRN (MRE11/Rad50/NBS1). Arginine methylation of hnRNPUL1 also regulates its recruitment to sites of DNA damage [137]. The DNA damage repair proteins, MRE11 and p53 binding protein (p53BP1), are methylated by PRMT1 which regulates their DNA exonuclease activity [138, 139] and localisation to DNA damage sites [140], respectively. PRMT1-deficient cells have an impaired ability to recruit Rad51 to DNA damage sites, causing chromosome instability and cell cycle arrest [141]. PRMT1 also regulates the activity of DNA polymerase $\beta$ by methylating arginine 137 within the PCNA binding site [142]. This prevents the binding of DNA polymerase $\beta$ and PCNA, implicating PRMT1 in regulation of BER specifically.

PRMT5 also regulates DNA damage repair through the methylation of Rad9 [143]. HEK293T cells without methylated Rad9 were more susceptible to DNA damage by hydroxyurea and led to increased $S / M$ and $G_{2} / M$ cell cycle checkpoint activation [143].

The DNA binding affinity of DNA polymerase $\beta$ and its ability to repair short single-stranded DNA breaks is enhanced by the methylation of DNA polymerase $\beta$ by PRMT6 [144].

Methylation of DNA repair protein, Flap endonuclease (FEN1) at arginine 192, enhances its localization to DNA repair sites [145]. Interestingly, a disruption in arginine methylation causes reduced binding to PCNA allowing the phosphorylation of FEN1 at serine 187 by the CDK2/ cyclin E complex, leading to decreased localization of
FEN1 at DNA repair sites and a delay in cell cycle progression [145].

\section{Regulation of indirect mediators of the cell cycle by arginine methylation}

In addition to the key regulatory proteins of cell cycle and DNA damage repair pathways discussed in the previous sections, other cellular proteins that can indirectly affect cell cycle progression are regulated by protein arginine methylation (see Table 3).

PRMT1 regulates telomere length and stability by the methylation of the Telomere repeat binding factor 2 (TRF2) [146]. Depletion of PRMT1 results in telomere doublets and promotes telomere shortening [146]. Methylation at arginine 887 of the Inner centromere protein (INCENP) by PRMT1 enhances its binding affinity to Aurora B [147]. A decrease in INCENP methylation led to repression of Aurora B activity resulting in abnormal chromosome alignment and segregation [147]. Arginine methylation of Ubiquitin-associated protein 2-like (UBAP2L) by PRMT1 is necessary for progression of mitosis by regulating chromosome alignment and distribution [44].

The estrogen receptor $\alpha(E R \alpha)$ is methylated by PRMT1 at arginine 260, resulting in cytoplasmic localisation of $\mathrm{ER} \alpha$ and indirectly prevents the downstream phosphorylation of the protein kinase $\beta / \alpha$ serine/threonine-protein kinase, PKB/AKT [148]. PRMT2 is another co-activator for the ER $\alpha$ and has been implicated in tumour cell growth and progression [149].

The androgen receptor (AR) found in the prostate plays a role in regulating the $G_{1} / S$ phase transition of the cell cycle in prostate cancer [150]. Inhibition of arginine methylation resulted in reduced expression of the $\mathrm{AR}$ and reduced cell proliferation [151]. PRMT2 acts as a co-activator of the AR, allowing translocation of both the AR and PRMT2 from the cytoplasm into the nucleus [152]. The AR also associates with PRMT9/10 in

Table 2 Key DNA damage repair proteins known to be substrates and interacting partners of PRMTs

\begin{tabular}{|c|c|c|c|c|}
\hline Protein & $\begin{array}{l}\text { Interacting } \\
\text { PRMT }\end{array}$ & $\begin{array}{l}\text { Known methylated resi- } \\
\text { dues }\end{array}$ & Result of methylation or PRMT interaction & Refs. \\
\hline \multirow[t]{2}{*}{ DNA polymerase $\beta$} & PRMT1 & R137 & Regulates binding to proliferating cell nuclear antigen & {$[142]$} \\
\hline & PRMT6 & $\mathrm{R} 83, \mathrm{R} 152$ & $\begin{array}{l}\text { Enhances DNA binding affinity of DNA polymerase } \beta \text { and } \\
\text { enhances repair ability }\end{array}$ & {$[144]$} \\
\hline FEN1 & Unknown & R192 & Enhances localization to DNA repair sites and binding to PCNA & {$[145]$} \\
\hline hnRNPUL1 & PRMT1 & $\mathrm{R} 584$, 5618, R620, R645, R656 & $\begin{array}{l}\text { Regulates interaction with NBS1 and recruitment to DNA dam- } \\
\text { age site }\end{array}$ & {$[137]$} \\
\hline MRE11 & PRMT1 & - & Regulation of DNA exonuclease activity & {$[138,139]$} \\
\hline p53BP1 & PRMT1 & R1400, R1401, R1403 & Enhanced localisation to DNA damage sites & {$[140]$} \\
\hline Rad9 & PRMT5 & $\mathrm{R} 172, \mathrm{R} 174, \mathrm{R} 175$ & Regulation of checkpoint activation & [143] \\
\hline
\end{tabular}


Table 3 Indirect mediators of the cell cycle known to be substrates and interacting partners of PRMTs

\begin{tabular}{|c|c|c|c|c|}
\hline Protein & Interacting PRMT & Known methylated residues & Result of methylation or PRMT interaction & Refs. \\
\hline \multirow[t]{3}{*}{ Androgen receptor } & PRMT2 & - & $\begin{array}{l}\text { Co-activator allowing translocation into the } \\
\text { nucleus }\end{array}$ & [152] \\
\hline & PRMT5 & - & Activator of the AR & [154] \\
\hline & PRMT10 & - & $\begin{array}{l}\text { Knockdown of PRMT10 suppressed cell } \\
\text { growth in LNCaP cells }\end{array}$ & [153] \\
\hline \multirow[t]{2}{*}{ CREB-binding protein } & PRMT4 & R600 & Disrupts CREB binding & [155] \\
\hline & & R742 & $\begin{array}{l}\text { Regulates transcriptional activation of steroid } \\
\text { hormone receptors }\end{array}$ & [156] \\
\hline \multirow[t]{2}{*}{ Estrogen receptor a } & PRMT1 & R260 & $\begin{array}{l}\text { Cytoplasmic localisation of ERa prevents } \\
\text { phosphorylation of PKB/AKT }\end{array}$ & [148] \\
\hline & PRMT2 & - & $\begin{array}{l}\text { Co-activator of ERa, implicated in tumour cell } \\
\text { growth }\end{array}$ & [149] \\
\hline INCENP & PRMT1 & R887 & $\begin{array}{l}\text { Enhances binding with inner centromere } \\
\text { protein (INCENP) to regulate chromosomal } \\
\text { alignment and segregation }\end{array}$ & [147] \\
\hline MDM4 & PRMT5 & - & $\begin{array}{l}\text { Alternate splicing of MDM4 activates p53 in } \\
\text { response to PRMT5 depletion }\end{array}$ & {$[172]$} \\
\hline \multirow[t]{2}{*}{ p300 } & PRMT4 & R580 & $\begin{array}{l}\text { Methylation of p300 activates p21 to inhibit } \\
\text { cell cycle progression }\end{array}$ & [155] \\
\hline & & R754 & $\begin{array}{l}\text { PRMT4 complexes with p } 300, \text { BRCA1 and p53 } \\
\text { to induce expression of p } 21\end{array}$ & [157] \\
\hline \multirow[t]{2}{*}{ Sam68 } & PRMT1 & $\begin{array}{l}\text { R45, R52, R304, R310, R315, R320, } \\
\text { R325 }\end{array}$ & $\begin{array}{l}\text { Methylation of Sam68 regulates its localiza- } \\
\text { tion and reduces its RNA-binding ability }\end{array}$ & $\begin{array}{l}{[169]} \\
{[170]}\end{array}$ \\
\hline & PRMT2 & - & Regulates alternative splicing of $\mathrm{BCl}-\mathrm{x}$ & [168] \\
\hline SF2/ASF & Unknown & R93, R97, R109 & $\begin{array}{l}\text { Regulates subcellular localization and activity } \\
\text { of SF2/ASF }\end{array}$ & [171] \\
\hline Telomere repeat binding factor 2 & PRMT1 & $\mathrm{R} 17, \mathrm{R} 18$ & Regulates telomere length and stability & [146] \\
\hline Ubiquitin-associated protein 2-like & PRMT1 & $\mathrm{N}$-terminus region & $\begin{array}{l}\text { Regulation of chromosome alignment during } \\
\text { mitosis }\end{array}$ & [44] \\
\hline
\end{tabular}

the prostate cancer cell line, $\mathrm{LNCaP}$, and knockdown of PRMT9/10 suppressed both cellular growth and expression of the prostate specific antigen (PSA) [153]. PRMT5 was recently found to function as an activator of the AR and regulator of AR-dependent proliferation in LNCaP cells and expression of PRMT5 also correlated with RNA and protein expression of the AR [154]. Although it is not yet known if the AR is methylated on arginine residues, it is clear that methylation plays an important role in ARmediated cell cycle progression, through the association with PRMTs.

The transcriptional activity of the acetyltransferases CREB-binding protein (CBP)/p300 is regulated by PRMT4-mediated methylation of p300, which is important for $G_{1} / S$ phase transition $[155,156]$. Methylation of p300 induces complex formation of PRMT4 and p300 with BRCA1 and p53 to induce expression of p21, hence inhibiting cell cycle progression [155, 157]. p300 also associates with PRMT5, Strap and JMY for arginine methylation of p53 which affects the promoter specificity of p53 and enhances p53-dependent cell cycle arrest [127].
Pathways involved in cell cycle regulation can also affect alternative splicing. The ATM/ATR pathways can regulate alternative splicing in response to DNA damage to promote pro-apoptotic genes [158]. Aurora kinase A inhibition caused downregulation of the splicing factor, SF2/ASF, to regulate bcl-x splicing to trigger apoptosis [159]. Interestingly, splicing factors and their products are often overexpressed in cancer, including ovarian [160], breast [161, 162], lung and colon [161]. hnRNPs are a prominent splicing factor family known to be methylated on arginine residues [163-165]. Serine-arginine rich (SR) splicing factors are another prominent splicing factor family [166] and it should come as no surprise that SR splicing factors are methylated due to the abundance of arginine residues they contain. The SR protein SF2A-p32 associates with PRMT1 and PRMT5 [167], while PRMT2 associates with multiple SR proteins and hnRNPs, including Sam68, to regulate alternative splicing of the mitochondrial protein Bcl-x [168]. Arginine methylation of Sam68 by PRMT1 localizes it to the cytoplasm [169] and reduces its RNA binding ability [170], thus indicating that Sam68 is highly regulated by arginine methylation. 
The localisation and therefore the function of SF2/ASF is also highly regulated by arginine methylation [171]. PRMT4 methylates the splicing factors CA150, SmB, $\mathrm{U} 1 \mathrm{C}$, and SAP49 and promotes exon skipping to regulate alternative pre-mRNA splicing [86]. Alternative splicing of the $\mathrm{p} 53$ regulator, MDM4, activates the $\mathrm{p} 53$ pathway in response to PRMT5 depletion [172]. The role of PRMTs in splicing has been reviewed by [173]. The effect of the methylation of splicing factors in cell cycle regulation and cancer needs to be further investigated.

From this review, it should have become evident, that the majority of proteins and pathways of the cell cycle reported to be deregulated in various cancers are also the ones that can be regulated via protein arginine methylation. Further, studies that suggest regulation of the DNA damage response by arginine methylation are accumulating $[44,137,138,140,142,144]$. These studies also implicate arginine methylation in the deregulation of DNA damage repair pathways which, if not rectified by the cell, may lead to genomic instability and eventually to the progression of cancer. Altered expression levels of PRMTs have been found in many types of cancer, reviewed by [94, 174], implicating their importance in cell cycle and proliferation, cell cycle checkpoints and DNA replication [175]. Therefore, protein arginine methylation may represent a novel target in the development of anti-cancer drugs.

\section{Implications for cancer treatment}

PRMT1 [176, 177], PRMT2 [178], PRMT4 [179], PRMT5 [180], PRMT7 [181], and PRMT8 [182] have been reported to have isoforms with differing subcellular locations and are expressed in different cancer types. For a review see [183]. Although Baldwin et al. [183] speculate that the cancer-specific isoforms may have different substrates, this is based on the different localisations of the isoforms which would allow access to different substrates [183]. It is currently unknown if these isoforms behave differently in their substrate-specificity or their activity. These cancer-specific PRMT isoforms could also be targets for future anti-cancer drug development. Drugs could potentially target the aberrant isoforms in cancerous cells without affecting the other isoforms required for normal cell function.

The opportunity may further exist to use PRMT inhibitors in combination with classic chemotherapy drugs. The currently widely used chemotherapy drug Taxol (Paclitaxel) binds to tubulin- $\beta$, causing stabilisation of microtubules during mitosis and inhibiting cell division [184]. Recently, protein arginine methylation in the Taxol-binding region of tubulin- $\beta$ was proposed to affect the binding ability of the drug [185]. This could pave the way for the use of methylation inhibitors as a parallel treatment with Taxol. Inhibiting arginine methylation of tubulin- $\beta$ would allow Taxol full access to the tubulin- $\beta$ binding site to inhibit cell division in a cancer- targeted therapy. Alternatively, Taxol derivatives that bind with higher affinity to methylated tubulin may be developed.

PRMT inhibitors could also be used in combination with chemotherapy drugs to combat chemoresistance. There are multiple known pathways of chemoresistance (for review see [186]). Activation of the NF- $k B$ proinflammatory pathway can activate the production of anti-apoptotic proteins resulting in tumour growth [187]; polymorphisms in ATP-binding cassette (ABC) multidrug efflux pumps can prevent drugs from crossing the blood-brain barrier and even pump drugs back out of target cells [188]; or DNA repair pathways can be upregulated to repair damage caused by DNA-damaging drugs [189, 190]. As discussed previously, PRMT1 methylates or associates with DNA repair proteins and in many cases, this regulates or enhances the binding of DNA repair proteins to the damage sites $[137,138,140,142-$ 145]. An inhibitor targeting PRMT1 could be used to disrupt the binding of DNA repair proteins to the DNA damage sites, thus preventing cancer cells from evading apoptosis. This treatment would need to be delivered in a tumor-targeting vector as PRMT1 knockdown is known to be embryonically lethal [141] and would also be damaging to non-tumorigenic cells.

Other drugs should be looked at with the possibility of combinatorial cancer therapies. As discussed previously, PRMT5 interacts with CDK4 to regulate pRb/E2Fmediated transcription. Knockdown of PRMT5 made HepG2 cells more sensitive to the CDK4 inhibitor fascaplysin [119]. While this is a promising study, fascaplysin has only been used on cell lines [191-194], and would require further study in order to be used for cancer therapy. PD0332991 (Palbociclib), was the first CDK4/6 inhibitor to be approved for cancer therapy. It is used in the treatment of $\mathrm{pRb}$ positive breast cancer [195], manthe cell lymphoma (MCL) [196], and liposarcoma [197]. This CDK4 inhibitor may also be a potential candidate for combination therapy with PRMTs. An earlier study showed that knockdown of PRMT7 sensitised HeLa cells to the DNA topoisomerase I inhibitor Camptothecin, although the authors did not investigate the mechanism of how this occurs [198]. PRMT7 does not have many known substrates and its PRMT type status has been a controversial topic in the past with some studies claiming it to be a type II PRMT [199], while others proposed it to be a type III PRMT [99]. Further research on the exact mechanism of methylation by PRMT7 is required before it can be considered as a target for combinatorial therapy.

As mentioned previously, PRMTs are often overexpressed in cancers, leading to aberrant methylation 
patterns. Inhibitors of arginine methylation may be useful to treat tumors by correcting increased levels of protein methylation which may deregulate the cell cycle, DNA damage repair and other important cellular functions. Arginine methyltransferase inhibitor-1 (AMI-1), is able to inhibit the coactivator function of PRMTs [200] while Adenosine dialdehyde (AdOx) inhibits $S$-adenosyl homocysteine hydrolase preventing methylation from occurring by a negative feedback mechanism [89]. Although AdOx does not inhibit PRMTs directly, several studies have shown that treatment of cell lines with high concentrations of $\mathrm{AdOx}$ induces a $\mathrm{G}_{2} / \mathrm{M}$ phase arrest of the cell cycle [201-203]. Inhibition of methylation with AdOx also showed a similar decreased growth rate and reduced migration activity when compared to PRMT1 knockdown cells [204]. This may be useful in treating tumors, if the inhibition of methylation by AdOx can be targeted towards tumor cells only. However, AdOx also causes a decrease in DNA, RNA and lysine methylation, thus further studies would be required to determine its suitability for treatment in vivo as well as the actual role of DNA, RNA and lysine methylation in cancer development.

Other non-specific PRMT inhibitors have been identified-MS023 binds to the active site of type I PRMTs [205]; while DS-437 acts on PRMTs 5 and 7 [206]. Inhibitors which are more specific to individual PRMTs would be preferential for combinatorial cancer therapy to minimise potential off-target effects. Promising specific PRMT inhibitors will be discussed below and have recently been reviewed [207].

PRMT1, being the most abundant PRMT [102], has been the target of the majority of PRMT-specific inhibitor development. Cyanine-derivative compounds have been synthesized based on the structure of AMI-1, such as E-84 which preferentially binds to PRMT1 over other PRMTs and has been demonstrated to decrease leukemia cell proliferation [208]. High-throughput screening was utilised to identify compounds to competitively bind to PRMT1 and PRMT8 [209]. Only PRMT1 and PRMT8 contain a hyper-reactive cysteine residue (C101) within the active site that comes into direct contact with S-adenosyl methionine during the methylation reaction [210]. CID5380390 and CID2818500 were found to produce the strongest inhibition with $\mathrm{IC}_{50}$ values of 23 and $11 \mu \mathrm{M}$, respectively [209]. CID5380390 was used to characterize PRMT activity in E. grandis roots [211]. However, no further studies have been published on the mechanism of action for either of these inhibitors.

The PRMT5-specific inhibitor, EPZ015666 (GSK3235 025), inhibited growth in a panel of five MCL cell lines and inhibited tumor growth in a dose-dependent manner in
MCL xenograft models [212]. The inhibitor structure was altered and renamed EPZ015938 and entered phase I clinical dose-escalation trials in 2016 as compound GSK3326595 for the treatment of solid tumors and non-Hodgkin's lymphoma (NCT02783300) [213].

More specific inhibition of individual methylated residues with peptide or small molecule inhibitors will present fewer side effects and will be the most likely successful design of personalised cancer treatment of the future. In line with this, a recent review discussed firstgeneration inhibitors of arginine methylation currently in pre-clinical or phase I/II clinical trials [214].

\section{Next steps}

While it is clear that protein arginine methylation is emerging as a key regulator of the cell cycle and may offer suitable targets for novel cancer drug development in the future, the immediate research effort should focus on a more detailed and complete cataloguing of PRMTs and their substrates at different stages of the cell cycle and in various cancer types. Hand in hand with this rather mammoth effort would need to be the development of more specific PRMT inhibitors to not only identify which substrate is methylated on which residue by what PRMT, but to also facilitate the study of downstream functions of the methylation and molecular mechanisms of arginine methylation including effects on alternative splicing. It should be noted that these arginine methylation modifications or aberrant PRMT expression levels could differ between cell/tissue type, between cancer types and even between individual patients. Further emphasis should be placed on unravelling the complex interplay and cross regulation of phosphorylation and methylation which has been so far reported in a few proteins but may be a more widespread regulatory mechanism of protein function that may offer further targets of intervention.

\section{Conclusions}

In the coming age of personalised cancer treatment, targeting the specific mutations and anomalous proteins of each patient's cancer will lead to increased recovery rates. Although our current knowledge of the role of arginine methylation in cell cycle control and cancer development is still in its infancy, it is clear that arginine methylation is an emerging key regulator of the cell cycle that rivals protein phosphorylation in its importance. Further studies are required to determine the exact role that protein arginine methylation plays within the cell cycle, and how this may be used to develop future cancer treatments to target aberrant protein arginine methylation. 


\begin{abstract}
Abbreviations
ABC: ATP-binding cassette; ADMA: asymmetric dimethylarginine; AdOx: adenosine dialdehyde oxidised; AKT/PKB: a serine/threonine-protein kinase/ protein kinase B; AMI1: arginine methyltransferase inhibitor 1; APC/C: anaphase-promoting complex/cyclosome; APE1: apurinic/apyrimidinic endonuclease; AR: androgen receptor; ATM: ataxia-telangiectasia mutated; ATR: ataxia-telangiectasia and rad3 related; BER: base excision repair; BRCA: tumor suppressor gene; BUB: budding uninhibited by benzimidazole; C: cysteine; CAK: CDK activating kinase; CBP: CREB-binding protein; CCNE1: cyclin E1 gene; CDC: cell division cycle phosphatase; CDK: cyclin-dependent kinase; CDKI: cyclin-dependent kinase inhibitor; Chk: checkpoint kinase; CIP: CDK interacting proteins; DNA: deoxyribonucleic acid; DP: transcription factor family; DSB: double strand break; E2F: transcription factor family; ER: estrogen receptor; ERCC1: DNA repair endonuclease; FEN1: flap endonuclease $1 ; G_{0}$ : resting phase of cell cycle; $G_{1}$ phase: first gap phase of cell cycle; $G_{2}$ phase: second gap phase of cell cycle; GADD45: growth arrest and DNA damage-inducible 45a; GAR: glycine-arginine rich; GSK3 3 : glycogen synthase kinase $3 \beta$; H: histidine; hnRNPUL1: heterogenous nuclear ribonucleo protein; INCENP: inner centromere protein; INK4: inhibitors of CDK4; JMY: junction mediating and regulatory protein; K: lysine; KIP: kinase inhibitory proteins; M phase: mitosis phase of cell cycle; MAD: mitotic-arrest deficient; MCC: mitotic checkpoint complex; MDM4: murine double minute 4; MMA: monomethyl arginine; MMS4: DNA repair endonuclease; MRE11: meiotic recombination 11; MRN: MRE11/ Rad51/Nbs1 complex; MUS81: DNA repair endonuclease; NBS1: nibrin; NHEJ: non-homologous end joining; p53: tumor suppressor protein p53; p53BP1: p53-binding protein 1; PCNA: proliferating cell nuclear antigen; PGM: proline glycine methionine motif; PI3K: phosphatidyl inositol-3-kinase; PKC: protein kinase C; PRb: retinoblastoma protein; PRMT: protein arginine methyltransferase; PSA: prostate specific antigen; PTEN: phosphatase and tensin homolog; R: arginine; Rad51: DNA recombination protein; RFC: replication factor C; RNA: ribonucleic acid; RPA: DNA repair protein; $S$ phase: DNA synthesis phase of cell cycle; SAC: spindle assembly checkpoint; SDMA: symmetric dimethylarginine; SF: splicing factor; SR: serine-arginine rich; TFIIH: transcription factor IIH; TRF: telomere repeat binding factor; UBAP2L: ubiquitin-associated protein 2-like; XPA: DNA repair protein; XPC: DNA repair gene; XPF: DNA repair endonuclease; XPG: DNA repair endonuclease; XRCC: DNA base excision repair gene.
\end{abstract}

\section{Authors' contributions}

AER and SCP contributed to writing the manuscript. Both authors read and approved the final manuscript.

\section{Acknowledgements}

The authors would like to acknowledge Dr. Liza Cubeddu for critically reviewing this manuscript.

\section{Competing interests}

The authors declare that they have no competing interests.

\section{Availability of data and materials}

Not applicable.

\section{Consent for publication}

Not applicable.

\section{Ethics approval and consent to participate}

Not applicable.

\section{Funding}

This work was supported by a Postgraduate Research Award from Western Sydney University (AER).

\section{Publisher's Note}

Springer Nature remains neutral with regard to jurisdictional claims in published maps and institutional affiliations.

Received: 20 December 2017 Accepted: 13 March 2018

Published online: 20 March 2018

\section{References}

1. Vermeulen K, Van Bockstaele DR, Berneman ZN. The cell cycle: a review of regulation, deregulation and therapeutic targets in cancer. Cell Prolif. 2003;36:131-49.

2. Manchado E, Guillamot M, Malumbres M. Killing cells by targeting mitosis. Cell Death Differ. 2012;19:369.

3. Park M-T, Lee S-J. Cell cycle and cancer. J Biochem Mol Biol. 2003;36:60-5

4. Yang Y, Bedford MT. Protein arginine methyltransferases and cancer. Nat Rev Cancer. 2013;13:37-50.

5. Norbury C, Nurse P. Animal cell cycles and their control. Annu Rev Biochem. 1992;61:441-68.

6. Schafer K. The cell cycle: a review. Vet Pathol Online. 1998;35:461-78.

7. Burgess A, Vuong J, Rogers S, Malumbres M, O'Donoghue SI. SnapShot: phosphoregulation of mitosis. Cell. 2017;169:1358.

8. Hanahan D, Weinberg RA. Hallmarks of cancer: the next generation. Cell. 2011;144:646-74.

9. Collins I, Garrett MD. Targeting the cell division cycle in cancer: CDK and cell cycle checkpoint kinase inhibitors. Curr Opin Pharmacol. 2005:5:366-73.

10. Maddika S, Ande SR, Panigrahi S, Paranjothy T, Weglarczyk K, Zuse A, Eshraghi M, Manda KD, Wiechec E, Los M. Cell survival, cell death and cell cycle pathways are interconnected: implications for cancer therapy. Drug Resist Updates. 2007;10:13-29.

11. Morgan DO. Principles of CDK regulation. Nature. 1995;374:131-4.

12. Pines J. Cyclins and cyclin-dependent kinases: theme and variations. Adv Cancer Res. 1995;66:181-212.

13. Evans T, Rosenthal ET, Youngblom J, Distel D, Hunt T. Cyclin: a protein specified by maternal mRNA in sea urchin eggs that is destroyed at each cleavage division. Cell. 1983;33:389-96.

14. Massague J. G1 cell-cycle control and cancer. Nature. 2004:432:298-306.

15. Malumbres M, Carnero A. Cell cycle deregulation: a common motif in cancer. Prog Cell Cycle Res. 2003;5:5-18.

16. Dobashi Y. Cell cycle regulation and its aberrations in human lung carcinoma. Pathol Int. 2005:55:95-105.

17. Jeffrey PD, Russo AA, Polyak K, Gibbs E, Hurwitz J, Massague J, Pavletich NP. Mechanism of CDK activation revealed by the structure of a cyclinACDK2 complex. Nature. 1995;376:313-20.

18. Lew DJ, Kornbluth S. Regulatory roles of cyclin dependent kinase phosphorylation in cell cycle control. Curr Opin Cell Biol. 1996;8:795-804.

19. Hirai H, Roussel MF, Kato JY, Ashmun RA, Sherr CJ. Novel INK4 proteins, p19 and p18, are specific inhibitors of the cyclin D-dependent kinases CDK4 and CDK6. Mol Cell Biol. 1995;15:2672-81.

20. Polyak K, Kato JY, Solomon MJ, Sherr CJ, Massague J, Roberts JM, Koff A. p27Kip1, a cyclin-Cdk inhibitor, links transforming growth factor-beta and contact inhibition to cell cycle arrest. Genes Dev. 1994:8:9-22.

21. Waga S, Li R, Stillman B. p53-induced p21 controls DNA replication. Leukemia. 1997;11(Suppl 3):321-3.

22. el-Deiry WS, Tokino T, Velculescu VE, Levy DB, Parsons R, Trent JM, Lin D, Mercer WE, Kinzler KW, Vogelstein B. WAF1, a potential mediator of p53 tumor suppression. Cell. 1993;75:817-25.

23. Zhang Z, Rosen DG, Yao JL, Huang J, Liu J. Expression of p14ARF, p15INK4b, p16INK4a, and DCR2 increases during prostate cancer progression. Mod Pathol. 2006;19:1339.

24. Liang J, Slingerland JM. Multiple roles of the PI3K/PKB (Akt) pathway in cell cycle progression. Cell Cycle. 2003;2:339-45.

25. Diehl JA, Cheng M, Roussel MF, Sherr CJ. Glycogen synthase kinase3beta regulates cyclin D1 proteolysis and subcellular localization. Genes Dev. 1998;12:3499-511.

26. Vivanco I, Sawyers CL. The phosphatidylinositol 3-kinase-AKT pathway in human cancer. Nat Rev Cancer. 2002;2:489-501.

27. Stambolic V, Suzuki A, De La Pompa JL, Brothers GM, Mirtsos C, Sasaki T, Ruland J, Penninger JM, Siderovski DP, Mak TW. Negative regulation of PKB/Akt-dependent cell survival by the tumor suppressor PTEN. Cell. 1998;95:29-39.

28. Ali IU, Schriml LM, Dean M. Mutational spectra of PTEN/MMAC1 gene: a tumor suppressor with lipid phosphatase activity. J Natl Cancer Inst. 1999:91:1922-32.

29. Malumbres M, Barbacid M. Cell cycle, CDKs and cancer: a changing paradigm. Nat Rev Cancer. 2009;9:153-66. 
30. Levine AJ. p53, the cellular gatekeeper for growth and division. Cell. 1997;88:323-31.

31. Paulovich AG, Hartwell LH. A checkpoint regulates the rate of progression through $\mathrm{S}$ phase in S. cerevisiae in response to DNA damage. Cell. 1995;82:841-7.

32. Kops GJ, Weaver BA, Cleveland DW. On the road to cancer: aneuploidy and the mitotic checkpoint. Nat Rev Cancer. 2005;5:773-85.

33. Hoyt MA, Totis L, Roberts BTS. S. cerevisiae genes required for cell cycle arrest in response to loss of microtubule function. Cell. 1991;66:507-17.

34. Li R, Murray AW. Feedback control of mitosis in budding yeast. Cell. 1991:66:519-31.

35. Sudakin V, Chan GK, Yen TJ. Checkpoint inhibition of the APC/C in HeLa cells is mediated by a complex of BUBR1, BUB3, CDC20, and MAD2. J Cell Biol. 2001;154:925-36.

36. Fang $\mathrm{G}, \mathrm{Yu}$ H, Kirschner MW. The checkpoint protein MAD2 and the mitotic regulator CDC20 form a ternary complex with the anaphasepromoting complex to control anaphase initiation. Genes Dev. 1998;12:1871-83.

37. Shannon KB, Canman JC, Salmon ED. Mad2 and BubR1 function in a single checkpoint pathway that responds to a loss of tension. Mol Bio Cell. 2002;13:3706-19.

38. Malureanu LA, Jeganathan KB, Hamada M, Wasilewski L, Davenport J, van Deursen JM. BubR1N terminus acts as a soluble inhibitor of cyclin B degradation by APC/CCdc20 in interphase. Dev Cell. 2009;16:118-31.

39. Hagting A, den Elzen N, Vodermaier HC, Waizenegger IC, Peters J-M, Pines J. Human securin proteolysis is controlled by the spindle checkpoint and reveals when the APC/C switches from activation by $\mathrm{Cdc} 20$ to Cdh1. J Cell Biol. 2002;157:1125-37.

40. Hauf S, Waizenegger IC, Peters JM. Cohesin cleavage by separase required for anaphase and cytokinesis in human cells. Science. 2001;293:1320-3.

41. D'Angiolella V, Mari C, Nocera D, Rametti L, Grieco D. The spindle checkpoint requires cyclin-dependent kinase activity. Genes Dev. 2003; 17:2520-5

42. Ditchfield C, Johnson VL, Tighe A, Ellston R, Haworth C, Johnson T, Mortlock A, Keen N, Taylor SS. Aurora B couples chromosome alignment with anaphase by targeting BubR1, Mad2, and Cenp-E to kinetochores. J Cell Biol. 2003;161:267-80.

43. Hauf S, Cole RW, LaTerra S, Zimmer C, Schnapp G, Walter R, Heckel A, van Meel J, Rieder CL, Peters JM. The small molecule Hesperadin reveals a role for Aurora B in correcting kinetochore-microtubule attachment and in maintaining the spindle assembly checkpoint. J Cell Biol. 2003;161:281-94.

44. Maeda M, Hasegawa H, Sugiyama M, Hyodo T, Ito S, Chen D, Asano E, Masuda A, Hasegawa Y, Hamaguchi M, et al. Arginine methylation of ubiquitin-associated protein 2-like is required for the accurate distribution of chromosomes. FASEB. 2015;30:312-23.

45. Musacchio A, Salmon ED. The spindle-assembly checkpoint in space and time. Nat Rev Mol Cell Biol. 2007:8:379-93.

46. Sancar A, Lindsey-Boltz LA, Unsal-Kacmaz K, Linn S. Molecular mechanisms of mammalian DNA repair and the DNA damage checkpoints. Annu Rev Biochem. 2004;73:39-85.

47. Abraham RT. Cell cycle checkpoint signaling through the ATM and ATR kinases. Genes Dev. 2001;15:2177-96.

48. Branzei D, Foiani M. Regulation of DNA repair throughout the cell cycle. Nat Rev Mol Cell Biol. 2008;9:297-308.

49. Kastan MB, Bartek J. Cell-cycle checkpoints and cancer. Nature. 2004;432:316-23.

50. Kunkel TA, Erie DA. DNA mismatch repair. Annu Rev Biochem. 2005:74:681-710.

51. Krokan H, Standal R, Slupphaug G. DNA glycosylases in the base excision repair of DNA. Biochem J. 1997;325:1-16.

52. Demple B, Jacobsson A, Olsson M, Robins P, Lindahl T. Repair of alkylated DNA in Escherichia coli. Physical properties of O6-methylguanine-DNA methyltransferase. J Biol Chem. 1982;257:13776-80.

53. Kubota Y, Nash RA, Klungland A, Schär P, Barnes D, Lindahl T. Reconstitution of DNA base excision-repair with purified human proteins: interaction between DNA polymerase beta and the XRCC1 protein. EMBO J. 1996;15:6662

54. Mayanagi K, Kiyonari S, Saito M, Shirai T, Ishino Y, Morikawa K. Mechanism of replication machinery assembly as revealed by the
DNA ligase-PCNA-DNA complex architecture. Proc Natl Acad Sci. 2009; 106:4647-52.

55. de Laat WL, Jaspers NG, Hoeijmakers JH. Molecular mechanism of nucleotide excision repair. Genes Dev. 1999;13:768-85.

56. Sancar A, Tang MS. Nucleotide excision repair. Photochem Photobiol. 1993;57:905-21.

57. O'Donovan A, Davies AA, Moggs JG, West SC, Wood RD. XPG endonuclease makes the $3^{\prime}$ incision in human DNA nucleotide excision repair. Nature. 1994:371:432.

58. He Z, Henricksen LA, Wold MS, Ingles CJ. RPA involvement in the damage-recognition and incision steps of nucleotide excision repair. Nature. 1995;374:566-9.

59. Araújo SJ, Nigg EA, Wood RD. Strong functional interactions of TFIIH with XPC and XPG in human DNA nucleotide excision repair, without a preassembled repairosome. Mol Cell Biol. 2001;21:2281-91.

60. Chu G. Double strand break repair. J Biol Chem. 1997;272:24097-100.

61. Ferguson DO, Alt FW. DNA double strand break repair and chromosomal translocation: lessons from animal models. Oncogene. 2001;20:5572-9.

62. Weterings $E_{\text {, Chen }} \mathrm{DJ}$. The endless tale of non-homologous end-joining. Cell Res. 2008;18:114-24.

63. Tauchi H, Kobayashi J, Morishima K, van Gent DC, Shiraishi T, Verkaik NS, Ito E, Nakamura A, Sonoda E, Takata M. Nbs1 is essential for DNA repair by homologous recombination in higher vertebrate cells. Nature. 2002;420:93-8

64. D'Amours D, Jackson SP. The Mre11 complex: at the crossroads of DNA repair and checkpoint signalling. Nat Rev Mol Cell Biol. 2002;3:317-27.

65. Baumann P, West SC. Role of the human RAD51 protein in homologous recombination and double-stranded-break repair. Trends Biochem Sci. 1998;23:247-51.

66. Davies AA, Masson J-Y, Mcllwraith MJ, Stasiak AZ, Stasiak A, Venkitaraman AR, West SC. Role of BRCA2 in control of the RAD51 recombination and DNA repair protein. Mol Cell. 2001;7:273-82.

67. Lees-Miller S, Meek K. Repair of DNA double strand breaks by nonhomologous end joining. Biochimie. 2003;85:1161-73.

68. Dronkert ML, Kanaar R. Repair of DNA interstrand cross-links. Mutat Res DNA Repair. 2001;486:217-47.

69. McHugh PJ, Spanswick VJ, Hartley JA. Repair of DNA interstrand crosslinks: molecular mechanisms and clinical relevance. Lancet Oncol. 2001:2:483-90.

70. Kuraoka I, Kobertz WR, Ariza RR, Biggerstaff M, Essigmann JM, Wood RD. Repair of an interstrand DNA cross-link initiated by ERCC1-XPF repair/ recombination nuclease. J Biol Chem. 2000;275:26632-6.

71. Finlan LE, Hupp TR. The life cycle of p53: a key target in drug development. Apoptotic pathways as targets for novel therapies in cancer and other diseases. Berlin: Springer; 2005. p. 157-72.

72. Peng CY, Graves PR, Thoma RS, Wu Z, Shaw AS, Piwnica-Worms H. Mitotic and G2 checkpoint control: regulation of 14-3-3 protein binding by phosphorylation of Cdc25C on serine-216. Science. 1997;277:1501-5.

73. Kim R, Emi M, Tanabe K. Role of mitochondria as the gardens of cell death. Cancer Chemother Pharmacol. 2006;57:545-53.

74. Giono LE, Manfredi JJ. The p53 tumor suppressor participates in multiple cell cycle checkpoints. J Cell Physiol. 2006;209:13-20.

75. Siliciano JD, Canman CE, Taya Y, Sakaguchi K, Appella E, Kastan MB. DNA damage induces phosphorylation of the amino terminus of p53. Genes Dev. 1997;11:3471-81.

76. Hanahan D, Weinberg RA. The hallmarks of cancer. Cell. 2000;100:57-70.

77. Knudsen ES, Knudsen KE. Retinoblastoma tumor suppressor: where cancer meets the cell cycle. Exp Biol Med. 2006;231:1271-81.

78. Lukas J, Parry D, Aagaard L, Mann DJ, Bartkova J, Strauss M, Peters G, Bartek J. Retinoblastoma-protein-dependent cell-cycle inhibition by the tumour suppressor p16. Nature. 1995;375:503-6.

79. Chellappan SP, Hiebert S, Mudryj M, Horowitz JM, Nevins JR. The E2F transcription factor is a cellular target for the RB protein. Cell. 1991;65:1053-61.

80. Connell-Crowley L, Harper JW, Goodrich D. Cyclin D1/Cdk4 regulates retinoblastoma protein-mediated cell cycle arrest by site-specific phosphorylation. Mol Biol Cell. 1997;8:287-301. 
81. Buchkovich K, Duffy LA, Harlow E. The retinoblastoma protein is phosphorylated during specific phases of the cell cycle. Cell. 1989:58:1097-105.

82. Bedford MT, Clarke S. Protein arginine methylation in mammals: who, what, and why. Mol Cell. 2009;33:1-13.

83. Lee YH, Stallcup MR. Minireview: protein arginine methylation of nonhistone proteins in transcriptional regulation. Mol Endocrinol. 2009;23:425.

84. Paik WK, Paik DC, Kim S. Historical review: the field of protein methylation. Trends Biochem Sci. 2007;32:146-52.

85. Altschuler L, Wook J-O, Gurari D, Chebath J, Revel M. Involvement of receptor-bound protein methyltransferase PRMT1 in antiviral and antiproliferative effects of type I interferons. J Interferon Cytokine Res. 1999;19:189-95.

86. Cheng D, Côté J, Shaaban S, Bedford MT. The arginine methyltransferase CARM1 regulates the coupling of transcription and mRNA processing Mol Cell. 2007;25:71-83.

87. Carr SM, Poppy Roworth A, Chan C, La Thangue NB. Post-translational control of transcription factors: methylation ranks highly. FEBS J. 2015:282:4450-65.

88. Côté J, Richard S. Tudor domains bind symmetrical dimethylated arginines. J Biol Chem. 2005;280:28476-83.

89. Pahlich S, Zakaryan RP, Gehring H. Protein arginine methylation: cellular functions and methods of analysis. BBA Proteins Proteom. 2006;1764:1890-903.

90. Friesen WJ, Paushkin S, Wyce A, Massenet S, Pesiridis GS, Van Duyne G, Rappsilber J, Mann M, Dreyfuss G. The methylosome, a 205 complex containing JBP1 and plCln, produces dimethylarginine-modified Sm proteins. Mol Cell Biol. 2001:21:8289-300.

91. Hadjikyriacou A, Yang Y, Espejo A, Bedford MT, Clarke SG. Unique features of human protein arginine methyltransferase 9 (PRMT9) and its substrate RNA splicing factor SF3B2. J Biol Chem. 2015;290:16723-43.

92. Blanc RS, Richard S. Arginine methylation: the coming of age. Mol Cell. 2017;65:8-24

93. Paik WK, Kim S. Protein methylase I. Purification and properties of the enzyme. J Biol Chem. 1968;243:2108-14

94. Wei H, Mundade R, Lange KC, Lu T. Protein arginine methylation of nonhistone proteins and its role in diseases. Cell Cycle. 2014;13:32-41.

95. Mirto L, Piller S. Protein arginine methylation: a pivotal factor and a target for novel HIV-therapeutics, other viruses and multiple diseases. HIV Ther. 2010;4:65-81.

96. Bedford MT. Arginine methylation at a glance. J Cell Sci. 2007; 120:4243-6.

97. Peng C, Wong CC. The story of protein arginine methylation: characterization, regulation, and function. Exp Rev Proteom. 2017;14:157-70.

98. Paik WK, Kim S. Natural occurrence of various methylated amino acid derivatives. In: Meister A, editor. Protein Methylation. New York:Wiley; 1980. p. 8-25

99. Zurita-Lopez Cl, Sandberg T, Kelly R, Clarke SG. Human protein arginine methyltransferase 7 (PRMT7) is a type III enzyme forming $\omega$-NGmonomethylated arginine residues. J Biol Chem. 2012;287:7859-70.

100. Fisk JC, Read LK. Protein arginine methylation in parasitic protozoa. Eukaryot Cell. 2011;10:1013-22.

101. Kim C, Lim Y, Yoo BC, Won NH, Kim S, Kim G. Regulation of post-translational protein arginine methylation during HeLa cell cycle. Biochem Biophys Acta. 2010;1800:977-85.

102. Tang J, Frankel A, Cook RJ, Kim S, Paik WK, Williams KR, Clarke S, Herschman HR. PRMT1 is the predominant type I protein arginine methyltransferase in mammalian cells. J Biol Chem. 2000;275:7723-30.

103. Dolezal E, Infantino S, Drepper F, Borsig T, Singh A, Wossning T, Fiala GJ, Minguet S, Warscheid B, Tarlinton DM, et al. The BTG2-PRMT1 module limits pre-B cell expansion by regulating the CDK4-Cyclin-D3 complex. Nat Immunol. 2017;18:911-20.

104. Zheng S, Moehlenbrink J, Lu Y-C, Zalmas L-P, Sagum CA, Carr S, McGouran JF, Alexander L, Fedorov O, Munro S, et al. Arginine methylationdependent reader-writer interplay governs growth control by E2F-1. Mol Cell. 2013;52:37-51.

105. Glorian V, Allègre J, Berthelet J, Dumetier B, Boutanquoi P-M, Droin N, Kayaci C, Cartier J, Gemble S, Marcion G, et al. DNA damage and S phase-dependent E2F1 stabilization requires the CIAP1 E3-ubiquitin ligase and is associated with K63-poly-ubiquitination on lysine 161/164 residues. Cell Death Dis. 2017;8:e2816.

106. Cho EC, Zheng S, Munro S, Liu G, Carr SM, Moehlenbrink J, Lu YC, Stimson L, Khan O, Konietzny R. Arginine methylation controls growth regulation by E2F-1. EMBO J. 2012;31:1785-97.

107. LuY, Ma W, Li Z, Lu J, Wang X. The interplay between p16 serine phosphorylation and arginine methylation determines its function in modulating cellular apoptosis and senescence. Sci Rep. 2017;7:41390.

108. Yoshimoto T, Boehm M, Olive M, Crook MF, San H, Langenickel T, Nabel EG. The arginine methyltransferase PRMT2 binds RB and regulates E2F function. Exp Cell Res. 2006;312:2040-53.

109. Kim KY, Wang D-H, Campbell M, Huerta SB, Shevchenko B, Izumiya C, Izumiya Y. PRMT4-mediated arginine methylation negatively regulates retinoblastoma tumor suppressor protein and promotes E2F-1 dissociation. Mol Cell Biol. 2015;35:238-48.

110. Oh TG, Bailey P, Dray E, Smith AG, Goode J, Eriksson N, Funder JW, Fuller PJ, Simpson ER, Tilley WD. PRMT2 and RORy expression are associated with breast cancer survival outcomes. Mol Endocrinol. 2014;28:1166-85

111. Zhong J, Cao RX, Liu JH, Liu YB, Wang J, Liu LP, Chen YJ, Yang J, Zhang $\mathrm{QH}, \mathrm{Wu}$ Y, et al. Nuclear loss of protein arginine $\mathrm{N}$-methyltransferase 2 in breast carcinoma is associated with tumor grade and overexpression of cyclin D1 protein. Oncogene. 2014;33:5546.

112. El Messaoudi S, Fabbrizio E, Rodriguez C, Chuchana P, Fauquier L, Cheng D, Theillet C, Vandel L, Bedford MT, Sardet C. Coactivator-associated arginine methyltransferase 1 (CARM1) is a positive regulator of the Cyclin E1 gene. Proc Natl Acad Sci. 2006;103:13351-6.

113. Frietze S, Lupien M, Silver PA, Brown M. CARM1 regulates estrogenstimulated breast cancer growth through up-regulation of E2F1. Cancer Res. 2008;68:301-6.

114. Hong H, Kao C, Jeng MH, Eble JN, Koch MO, Gardner TA, Zhang S, Li L, Pan CX, Hu Z. Aberrant expression of CARM1, a transcriptional coactivator of androgen receptor, in the development of prostate carcinoma and androgen-independent status. Cancer. 2004;101:83-9.

115. Pal S, Vishwanath SN, Erdjument-Bromage H, Tempst P, Sif S. Human SWI/SNF-associated PRMT5 methylates histone $\mathrm{H} 3$ arginine 8 and negatively regulates expression of ST7 and NM23 tumor suppressor genes. Mol Cell Biol. 2004:24:9630-45.

116. Wei TY, Juan CC, Hisa JY, Su L, Lee YC, Chou HY, Chen JM, Wu YC, Chiu $\mathrm{SC}, \mathrm{Hsu} C \mathrm{CP}$, et al. Protein arginine methyltransferase 5 is a potential oncoprotein that upregulates G1 cyclins/cyclin-dependent kinases and the phosphoinositide 3-kinase/AKT signaling cascade. Cancer Sci. 2012;103:1640-50

117. Scoumanne A, Zhang J, Chen X. PRMT5 is required for cell-cycle progression and p53 tumor suppressor function. Nucleic Acids Res. 2009:37:4965-76.

118. Yan F, Alinari L, Lustberg ME, Martin LK, Cordero-Nieves HM, BanasavadiSiddegowda Y, Virk S, Barnholtz-Sloan J, Bell EH, Wojton J, et al. Genetic validation of the protein arginine methyltransferase PRMT5 as a candidate therapeutic target in glioblastoma. Cancer Res. 2014;74:1752-65.

119. Yang H, Zhao X, Zhao L, Liu L, Li J, Jia W, Liu J, Huang G. PRMT5 competitively binds to CDK4 to promote G1-S transition upon glucose induction in hepatocellular carcinoma. Oncotarget. 2016:7:72131-47.

120. Banasavadi-Siddegowda Y, Russell L, Frair E, Karkhanis V, Relation T, Yoo J, Zhang J, Sif S, Imitola J, Baiocchi R. PRMT5-PTEN molecular pathway regulates senescence and self-renewal of primary glioblastoma neurosphere cells. Oncogene. 2017;36:263.

121. Kumar B, Yadav A, Brown NV, Zhao S, Cipolla MJ, Wakely PE, Schmitt AC, Baiocchi RA, Teknos TN, Old M, et al. Nuclear PRMT5, cyclin D1 and IL-6 are associated with poor outcome in oropharyngeal squamous cell carcinoma patients and is inversely associated with p16-status. Oncotarget. 2017:8:14847-59.

122. Han X, Li R, Zhang W, Yang X, Wheeler CG, Friedman GK, Province P, Ding Q, You Z, Fathallah-Shaykh HM, et al. Expression of PRMT5 correlates with malignant grade in gliomas and plays a pivotal role in tumor growth in vitro. J Neurooncol. 2014;118:61-72.

123. Gu Z, Gao S, Zhang F, Wang Z, Ma W, Davis RE, Wang Z. Protein arginine methyltransferase 5 is essential for growth of lung cancer cells. Biochem J. 2012:446:235. 
124. Pal S, Baiocchi RA, Byrd JC, Grever MR, Jacob ST, Sif S. Low levels of miR-92b/96 induce PRMT5 translation and H3R8/H4R3 methylation in mantle cell lymphoma. EMBO J. 2007;26:3558-69.

125. Bao X, Zhao S, Liu T, Liu Y, Liu Y, Yang X. Overexpression of PRMT5 promotes tumor cell growth and is associated with poor disease prognosis in epithelial ovarian cancer. J Histochem Cytochem. 2013;61:206-17.

126. Gu Z, Li Y, Lee P, Liu T, Wan C, Wang Z. Protein arginine methyltransferase 5 functions in opposite ways in the cytoplasm and nucleus of prostate cancer cells. PLoS ONE. 2012;7:e44033.

127. Jansson M, Durant ST, Cho E-C, Sheahan S, Edelmann M, Kessler B, La Thangue NB. Arginine methylation regulates the p53 response. Nat Cell Biol. 2008;10:1431-9.

128. Jung SY, Li Y, Wang Y, Chen Y, Zhao Y, Qin J. Complications in the assignment of 14 and 28 Da mass shift detected by mass spectrometry as in vivo methylation from endogenous proteins. Anal Chem. 2008;80:1721-9.

129. Zhang Y, Zhang YJ, Zhao HY, Zhai QL, Zhang Y, Shen YF. The impact of R213 mutation on p53-mediated p21 activity. Biochimie. 2014;99:215-8.

130. Cheung RS, Taniguchi T. Recent insights into the molecular basis of Fanconi anemia: genes, modifiers, and drivers. Int J Hematol. 2017;106:335-44.

131. Du W, Amarachintha S, Erden O, Wilson A, Pang Q. The Fanconi anemia pathway controls oncogenic response in hematopoietic stem and progenitor cells by regulating PRMT5-mediated p53 arginine methylation. Oncotarget. 2016;7:60005-20.

132. Kleinschmidt MA, De Graaf P, Van Teeffelen HA, Timmers HTM. Cell cycle regulation by the PRMT6 arginine methyltransferase through repression of cyclin-dependent kinase inhibitors. PLOS ONE. 2012;7:e41446.

133. Stein C, Riedl S, Rüthnick D, Nötzold RR, Bauer U-M. The arginine methyltransferase PRMT6 regulates cell proliferation and senescence through transcriptional repression of tumor suppressor genes. Nucleic Acids Res. 2012;40:9522-33.

134. Phalke S, Mzoughi S, Bezzi M, Jennifer N, Mok WC, Low DH, Thike AA Kuznetsov VA, Tan PH, Voorhoeve PM. p53-Independent regulation of p21Waf1/Cip1 expression and senescence by PRMT6. Nucleic Acids Res. 2012;40:9534-42

135. Nakakido M, Deng Z, Suzuki T, Dohmae N, Nakamura Y, Hamamoto R. PRMT6 increases cytoplasmic localization of p21CDKN1A in cancer cells through arginine methylation and makes more resistant to cytotoxic agents. Oncotarget. 2015;6:30957-67.

136. Wang X, Huang Y, Zhao J, Zhang Y, Lu J, Huang B. Suppression of PRMT6-mediated arginine methylation of p16 protein potentiates its ability to arrest A549 cell proliferation. Int J Biochem Cell Biol. 2012:44:2333-41.

137. Gurunathan G, Yu Z, Coulombe Y, Masson JY, Richard S. Arginine methylation of hnRNPUL1 regulates interaction with NBS1 and recruitment to sites of DNA damage. Sci Rep. 2015;5:10475.

138. Boisvert FM, Hendzel MJ, Masson JY, Richard S. Methylation of MRE1 1 regulates its nuclear compartmentalization. Cell Cycle. 2005;4:981-9.

139. Dery U, Coulombe Y, Rodrigue A, Stasiak A, Richard S, Masson JY. A glycine-arginine domain in control of the human MRE11 DNA repair protein. Mol Cell Biol. 2008;28:3058-69.

140. Boisvert F-M, Rhie A, Richard S, Doherty AJ. The GAR motif of 53BP1 is arginine methylated by PRMT1 and is necessary for 53BP1 DNA binding activity. Cell Cycle. 2005:4:1834-41.

141. Yu Z, Chen T, Hébert J, Li E, Richard S. A mouse PRMT1 null allele defines an essential role for arginine methylation in genome maintenance and cell proliferation. Mol Cell Biol. 2009;29:2982-96.

142. El-Andaloussi N, Valovka T, Toueille M, Hassa PO, Gehrig P, Covic M, Hübscher $U$, Hottiger MO. Methylation of DNA polymerase $\beta$ by protein arginine methyltransferase 1 regulates its binding to proliferating cell nuclear antigen. FASEB J. 2007:21:26-34.

143. He W, Ma X, Yang X, Zhao Y, Qiu J, Hang H. A role for the arginine methylation of Rad9 in checkpoint control and cellular sensitivity to DNA damage. Nucleic Acids Res. 2011;39:4719-27.

144. El-Andaloussi N, Valovka T, Toueille M, Steinacher R, Focke F, Gehrig P, Covic M, Hassa PO, Schär P, Hübscher U. Arginine methylation regulates DNA polymerase $\beta$. Mol Cell. 2006;22:51-62.

145. Guo Z, Zheng L, Xu H, Dai H, Zhou M, Pascua MR, Chen QM, Shen B. Methylation of FEN1 suppresses nearby phosphorylation and facilitates PCNA binding. Nat Chem Biol. 2010;6:766-73.
146. Mitchell TR, Glenfield K, Jeyanthan K, Zhu X-D. Arginine methylation regulates telomere length and stability. Mol Cell Biol. 2009;29:4918-34.

147. Deng X, Von Keudell G, Suzuki T, Dohmae N, Nakakido M, Piao L, Yoshioka $Y$, Nakamura $Y$, Hamamoto R. PRMT1 promotes mitosis of cancer cells through arginine methylation of INCENP. Oncotarget. 2015;6:35173-82

148. Poulard C, Rambaud J, Hussein N, Corbo L, Le Romancer M. JMJD6 regulates ERa methylation on arginine. PLOS ONE. 2014;9:e87982.

149. Qi C, Chang J, Zhu Y, Yeldandi AV, Rao SM, Zhu Y-J. Identification of protein arginine methyltransferase 2 as a coactivator for estrogen receptor a. J Biol Chem. 2002:277:28624-30.

150. Knudsen KE, Arden KC, Cavenee WK. Multiple G1 regulatory elements control the androgen-dependent proliferation of prostatic carcinoma cells. J Biol Chem. 1998;273:20213-22.

151. Shiota M, Takeuchi A, Yokomizo A, Kashiwagi E, Tatsugami K, Naito S. Methyltransferase inhibitor adenosine dialdehyde suppresses androgen receptor expression and prostate cancer growth. J Urol. 2012;188:300.

152. Meyer R, Wolf SS, Obendorf M. PRMT2, a member of the protein arginine methyltransferase family, is a coactivator of the androgen receptor. J Steroid Biochem Mol Biol. 2007;107:1-14.

153. Harada N, Takagi T, Nakano Y, Yamaji R, Inui H. Protein arginine methyltransferase 10 is required for androgen-dependent proliferation of LNCaP prostate cancer cells. Biosci Biotechnol Biochem. 2015;79:1-8.

154. Deng X, Shao G, Zhang HT, Li C, Zhang D, Cheng L, Elzey BD, Pili R, Ratliff TL, Huang J, et al. Protein arginine methyltransferase 5 functions as an epigenetic activator of the androgen receptor to promote prostate cancer cell growth. Oncogene. 2017;36:1223-31.

155. Xu W, Chen H, Du K, Asahara H, Tini M, Emerson BM, Montminy M, Evans RM. A transcriptional switch mediated by cofactor methylation. Science. 2001;294:2507-11.

156. Chevillard-Briet M, Trouche D, Vandel L. Control of CBP co-activating activity by arginine methylation. EMBO J. 2002;21:5457-66.

157. Lee YH, Bedford MT, Stallcup MR. Regulated recruitment of tumor suppressor BRCA1 to the p21 gene by coactivator methylation. Genes Dev. 2011;25:176-88.

158. Katzenberger RJ, Marengo MS, Wassarman DA. ATM and ATR pathways signal alternative splicing of Drosophila TAF1 pre-mRNA in response to DNA damage. Mol Cell Biol. 2006;26:9256-67.

159. Moore MJ, Wang Q, Kennedy CJ, Silver PA. An alternative splicing network links cell-cycle control to apoptosis. Cell. 2010;142:625-36.

160. Fischer D-C, Noack K, Runnebaum IB, Watermann DO, Kieback DG, Stamm S, Stickeler E. Expression of splicing factors in human ovarian cancer. Oncol Rep. 2004;11:1085-90.

161. Karni R, de Stanchina E, Lowe SW, Sinha R, Mu D, Krainer AR. The gene encoding the splicing factor SF2/ASF is a proto-oncogene. Nat Struct Mol Biol. 2007;14:185-93.

162. Stickeler E, Kittrell F, Medina D, Berget SM. Stage-specific changes in SR splicing factors and alternative splicing in mammary tumorigenesis. Oncogene. 1999:18:3574-82.

163. Liu Q, Dreyfuss G. In vivo and in vitro arginine methylation of RNAbinding proteins. Mol Cell Biol. 1995;15:2800-8.

164. Shen EC, Henry MF, Weiss VH, Valentini SR, Silver PA, Lee MS. Arginine methylation facilitates the nuclear export of hnRNP proteins. Genes Dev. 1998;12:679-91.

165. Chen Y, Zhou X, Liu N, Wang C, Zhang L, Mo W, Hu G. Arginine methylation of hnRNP K enhances p53 transcriptional activity. FEBS Lett. 2008;582:1761-5.

166. Ratnadiwakara M, Mohenska M, Anko ML. Splicing factors as regulators of miRNA biogenesis_links to human disease. Semin Cell Dev Biol. 2017. https://doi.org/10.1016/j.semcdb.2017.10.008

167. Yanagida M, Hayano T, Yamauchi Y, Shinkawa T, Natsume T, Isobe T, Takahashi N. Human fibrillarin forms a sub-complex with splicing factor 2-associated p32, protein arginine methyltransferases, and tubulins alpha 3 and beta 1 that is independent of its association with preribosomal ribonucleoprotein complexes. J Biol Chem. 2004;279:1607-14.

168. Vhuiyan ML, Pak ML, Park MA, Thomas D, Lakowski TM, Chalfant CE, Frankel A. PRMT2 interacts with splicing factors and regulates the alternative splicing of BCL-X. J Biochem. 2017;162:17-25.

169. Co^té J, Boulanger M-C, Bedford MT, Richard S. Sam68 RNA binding protein is an in vivo substrate for protein arginine $\mathrm{N}$-methyltransferase 1. Mol Biol Cell. 2003:14:274-87. 
170. Rho J, Choi S, Jung C-R, Im D-S. Arginine methylation of Sam68 and SLM proteins negatively regulates their poly (U) RNA binding activity. Arch Biochem Biophys. 2007;466:49-57.

171. Sinha R, Allemand E, Zhang Z, Karni R, Myers MP, Krainer AR. Arginine methylation controls the subcellular localization and functions of the oncoprotein splicing factor SF2/ASF. Mol Cell Biol. 2010;30:2762-74.

172. Bezzi M, Teo SX, Muller J, Mok WC, Sahu SK, Vardy LA, Bonday ZQ, Guccione E. Regulation of constitutive and alternative splicing by PRMT5 reveals a role for Mdm4 pre-mRNA in sensing defects in the spliceosomal machinery. Genes Dev. 2013;27:1903-16.

173. Yu MC. The role of protein arginine methylation in mRNP dynamics. Mol Biol Int. 2011;2011:163827.

174. Poulard C, Corbo L, Le Romancer M. Protein arginine methylation/demethylation and cancer. Oncotarget. 2016;7:67532-50.

175. Yoshimatsu M, Toyokawa G, Hayami S, Unoki M, Tsunoda T, Field HI, Kelly JD, Neal DE, Maehara Y, Ponder BAJ, et al. Dysregulation of PRMT1 and PRMT6, type I arginine methyltransferases, is involved in various types of human cancers. Int J Cancer. 2011;128:562.

176. Mathioudaki K, Papadokostopoulou A, Scorilas A, Xynopoulos D, Agnanti N, Talieri M. The PRMT1 gene expression pattern in colon cancer. Br J Cancer. 2008;99:2094-9.

177. Baldwin RM, Bejide M, Trinkle-Mulcahy L, Cote J. Identification of the PRMT1V1 and PRMT1V2 specific interactomes by quantitative mass spectrometry in breast cancer cells. Proteomics. 2015;15:2187-97.

178. Zhong J, Cao RX, Zu XY, Hong T, Yang J, Liu L, Xiao XH, Ding WJ, Zhao Q, $\mathrm{Liu} \mathrm{JH}$, et al. Identification and characterization of novel spliced variants of PRMT2 in breast carcinoma. FEBS J. 2012:279:316-35.

179. Ohkura N, Takahashi M, Yaguchi H, Nagamura Y, Tsukada T. Coactivatorassociated arginine methyltransferase 1, CARM1, affects pre-mRNA splicing in an isoform-specific manner. J Biol Chem. 2005;280:28927-35

180. Sohail M, Zhang M, Litchfield D, Wang L, Kung S, Xie J. Differential expression, distinct localization and opposite effect on Golgi structure and cell differentiation by a novel splice variant of human PRMT5. BBA Mol Cell Res. 2015;1853:2444-52.

181. Gros L, Renodon-Corniere A, de Saint Vincent BR, Feder M, Bujnicki $J M$, Jacquemin-Sablon A. Characterization of prmt7alpha and beta isozymes from Chinese hamster cells sensitive and resistant to topoisomerase II inhibitors. Biochem Biophys Acta. 2006;1760:1646-56.

182. Hernandez S, Dominko T. Novel protein arginine methyltransferase 8 isoform is essential for cell proliferation. J Cell Biochem. 2016;117:2056-66.

183. Baldwin RM, Morettin A, Cote J. Role of PRMTs in cancer: could minor isoforms be leaving a mark? World J Biol Chem. 2014:5:115-29.

184. Parness J, Horwitz SB. Taxol binds to polymerized tubulin in vitro. J Cell Biol. 1981:91:479-87.

185. Piller S, Jwad N, Hejazi L, Gamsjaeger R, Sucher N. Protein arginine methylation of tubulin beta decreases binding of taxol in Neuro2a cells. FASEB J. 2015;29(717):16.

186. Pan ST, Li ZL, He ZX, Qiu JX, Zhou SF. Molecular mechanisms for tumour resistance to chemotherapy. Clin Exp Pharmacol Physiol. 2016:43:723-37.

187. Chen R, Alvero AB, Silasi DA, Mor G. Inflammation, cancer and chemoresistance: taking advantage of the toll-like receptor signaling pathway. Am J Reprod Immunol. 2007:57:93-107.

188. Sharom FJ. ABC multidrug transporters: structure, function and role in chemoresistance. Pharmacogenomics. 2008:9:105-27.

189. Soengas MS, Lowe SW. Apoptosis and melanoma chemoresistance. Oncogene. 2003:22:3138-51.

190. Itamochi H, Kigawa J, Terakawa N. Mechanisms of chemoresistance and poor prognosis in ovarian clear cell carcinoma. Cancer Sci. 2008;99:653-8.

191. Chen S, Guan X, Wang L-L, Li B, Sang X-B, Liu Y, Zhao Y. Fascaplysin inhibit ovarian cancer cell proliferation and metastasis through inhibiting CDK4. Gene. 2017;635:3-8.

192. Segraves NL, Robinson SJ, Garcia D, Said SA, Fu X, Schmitz FJ, Pietraszkiewicz H, Valeriote FA, Crews P. Comparison of fascaplysin and related alkaloids: a study of structures, cytotoxicities, and sources. J Nat Prod. 2004;67:783-92.

193. Lu X-L, Zheng Y-L, Chen H-M, Yan X-J, Wang F, Xu W-F. Anti-proliferation of human cervical cancer HeLa cell line by fascaplysin through apoptosis induction. Yao Xue Xue Bao. 2009:44:980-6.

194. Hamilton G. Cytotoxic effects of fascaplysin against small cell lung cancer cell lines. Marine Drugs. 2014;12:1377-89.
195. DeMichele A, Clark AS, Tan KS, Heitjan DF, Gramlich K, Gallagher M, Lal P, Feldman M, Zhang P, Colameco C, et al. CDK 4/6 inhibitor palbociclib (PD0332991) in Rb + advanced breast cancer: phase Il activity, safety, and predictive biomarker assessment. Clin Cancer Res. 2015;21:995.

196. Leonard JP, LaCasce AS, Smith MR, Noy A, Chirieac LR, Rodig SJ, Yu JQ Vallabhajosula S, Schoder H, English P, et al. Selective CDK4/6 inhibition with tumor responses by PD0332991 in patients with mantle cell lymphoma. Blood. 2012;119:4597.

197. Dickson MA, Tap WD, Keohan ML, D'Angelo SP, Gounder MM, Antonescu CR, Landa J, Qin L-X, Rathbone DD, Condy MM, et al. Phase II trial of the CDK4 inhibitor PD0332991 in patients with advanced CDK4Amplified well-differentiated or dedifferentiated liposarcoma. J Clin Oncol. 2013:31:2024-8.

198. Verbiest V, Montaudon D, Tautu MT, Moukarzel J, Portail J-P, Markovits J, Robert J, Ichas F, Pourquier P. Protein arginine ( $N$ )-methyl transferase 7 (PRMT7) as a potential target for the sensitization of tumor cells to camptothecins. FEBS Lett. 2008;582:1483-9.

199. Lee J-H, Cook JR, Yang Z-H, Mirochnitchenko O, Gunderson SI, Felix AM, Herth N, Hoffmann R, Pestka S. PRMT7, a new protein arginine methyltransferase that synthesizes symmetric dimethylarginine. J Biol Chem. 2005;280:3656-64.

200. Bedford MT, Richard S. Arginine methylation: an emerging regulator of protein function. Mol Cell. 2005;18:263-72.

201. Dasgupta A, Jung KJ, Jeong SJ, Brady JN. Inhibition of methyltransferases results in induction of G2/M checkpoint and programmed cell death in human T-lymphotropic virus type 1-transformed cells. J Virol. 2008:82:49-59.

202. Heit R, Rattner JB, Chan GK, Hendzel MJ. G2 histone methylation is required for the proper segregation of chromosomes. J Cell Sci. 2009;122:2957-68.

203. Schwerk C, Schulze-Osthoff K. Methyltransferase inhibition induces p53-dependent apoptosis and a novel form of cell death. Oncogene. 2005:24:7002-11.

204. Chuang CY, Chang CP, Lee YJ, Lin WL, Chang WW, Wu JS, Cheng YW, Lee H, Li C. PRMT1 expression is elevated in head and neck cancer and inhibition of protein arginine methylation by adenosine dialdehyde or PRMT1 knockdown downregulates proliferation and migration of oral cancer cells. Oncol Rep. 2017;38:1115-23.

205. Eram MS, Shen Y, Szewczyk M, Wu H, Senisterra G, Li F, Butler KV, Kaniskan HU, Speed BA, Dela Sena C, et al. A potent, selective, and cell-active inhibitor of human type i protein arginine methyltransferases. ACS Chem Biol. 2016:11:772-81.

206. Smil D, Eram MS, Li F, Kennedy S, Szewczyk MM, Brown PJ, BarsyteLovejoy D, Arrowsmith CH, Vedadi M, Schapira M. Discovery of a dual PRMT5-PRMT7 inhibitor. ACS Med Chem Lett. 2015;6:408-12.

207. Hu H, Qian K, Ho MC, Zheng YG. Small molecule inhibitors of protein arginine methyltransferases. Expert Opin Investig Drugs. 2016;25:335-58.

208. Hu H, Owens EA, Su H, Yan L, Levitz A, Zhao X, Henary M, Zheng YG. Exploration of cyanine compounds as selective inhibitors of protein arginine methyltransferases: synthesis and biological evaluation. J Med Chem. 2015:58:1228-43.

209. Dillon MB, Bachovchin DA, Brown SJ, Finn MG, Rosen H, Cravatt BF, Mowen KA. Novel inhibitors for PRMT1 discovered by high-throughput screening using activity-based fluorescence polarization. ACS Chem Biol. 2012;7:1198-204

210. Weerapana E, Wang C, Simon GM, Richter F, Khare S, Dillon MBD, Bachovchin DA, Mowen K, Baker D, Cravatt BF. Quantitative reactivity profiling predicts functional cysteines in proteomes. Nature. 2010;468:790-5.

211. Plett KL, Raposo AE, Bullivant S, Anderson IC, Piller SC, Plett JM. Root morphogenic pathways in Eucalyptus grandis are modified by the activity of protein arginine methyltransferases. BMC Plant Biol. 2017;17:62.

212. Chan-Penebre E, Kuplast KG, Majer CR, Boriack-Sjodin PA, Wigle TJ, Johnston LD, Rioux N, Munchhof MJ, Jin L, Jacques SL, et al. A selective inhibitor of PRMT5 with in vivo and in vitro potency in MCL models. Nat Chem Biol. 2015;11:432-7.

213. Castillo-Aguilera O, Depreux P, Halby L, Arimondo PB, Goossens L. DNA Methylation Targeting: the DNMT/HMT crosstalk challenge. Biomolecules. 2017:7:3.

214. Hamamoto R, Nakamura Y. Dysregulation of protein methyltransferases in human cancer: an emerging target class for anticancer therapy. Cancer Sci. 2016;107:377-84. 